\title{
Recent blooms of the dinoflagellate Ceratium in Albert Falls Dam (KZN): History, causes, spatial features and impacts on a reservoir ecosystem and its zooplankton
}

\author{
Rob C Hart* and Peter D Wragg \\ School of Biological and Conservation Sciences, University of KwaZulu-Natal, Pietermaritzburg, South Africa
}

\begin{abstract}
A lake-wide bloom of the dinoflagellate Ceratium hirundinella, discovered in Albert Falls Dam in October 2006, exposed a significant ecological change indicative of reduced water quality in this historically mesotrophic reservoir. The spatial distribution of the bloom was examined synoptically in October 2006 and January 2007; these surveys revealed generally higher dinoflagellate densities in inshore reaches of the lake, and especially in the discharge plume of the inflowing Mgeni River. Ceratium totally dominated the phytoplankton assemblage, accounting almost completely for coincident chlorophyll levels, which generally increased with depth to generate a 'deep' chlorophyll maximum. Vertical oxygen profiles during the bloom differed substantially from corresponding profiles during non-bloom conditions historically typical in this reservoir. Direct count data and ordination analysis using non-metric multidimensional scaling exposed marked changes in zooplankton community structure compared to seasonally congruent non-bloom conditions in other years. Changes included the effective replacement of Moina by Bosmina, substantial reductions in Daphnia and Ceriodaphnia, and smaller but definite increases in abundance especially of calanoid copepods, as well as cyclopoid copepods and of Chaoborus, although not all of these differences were apparent in both survey months. These compositional changes are attributable to intrinsic differences in feeding biology among taxa and their associated susceptibility to the altered food environment, which was commensurate with Ceratium's emergence. In addition, chydorid cladocerans appeared as a new (but spatially restricted) eutrophic bio-indicator component of the zooplankton, and the species diversity of cyclopoid copepods was enriched.

The historical incidence of Ceratium in the lake since 1995 coincided with low $\mathrm{NO}_{3}-\mathrm{N}: \mathrm{TP}$ values (used here as an N:P ratio proxy), particularly of inflow waters, and with broadly coincident values in the open lake. Ceratium was present but sparse in 1995, at average N:P ratios around 5.5. It disappeared in 1996 when the ratio increased radically to $>10$, and reappeared in 2004 after an erratic decline of the ratio to $<5$ in the lake. The decline in N:P ratio of inflow waters since 1996 was clearly associated with a consistent rise in TP levels in inflows, most plausibly attributable to inputs of (Howick) wastewater treatment (WWT) plant origin. The appearance of Ceratium blooms is accordingly related to progressive elevations in mean annual P concentrations in inflows from $\sim 40 \mu \mathrm{g} / \ell$ in 1995 to $120 \mu \mathrm{g} / \ell \mathrm{in} 2007$ (broadly mirrored in annual TP loadings), suggesting that improved operational efficiency (and capacity) of the WWT plant offers a plausible prospect for mitigation and reversal.
\end{abstract}

Keywords: dinoflagellate blooms, eutrophication, water-quality, plankton community composition, ecosystem consequences, mitigation prospects

\section{Introduction}

An expansive literature (not reviewed here) attests that blooms of dinoflagellates (Ceratium and Peridinium species) have become widespread and prominent in many lentic freshwaters, while coastal marine environments have experienced similar blooms ('red tides') especially in the past 3 decades (e.g. Reynolds, 2006). The incidence, severity and prominence of bloom events in standing freshwater ecosystems appear to be growing exponentially, although the causes of such outbreaks remain ambiguous and/or contradictory. The relatively sudden onset of blooms of Ceratium hirundinella (O.F. Müller) Bergh in lakes and reservoirs is especially noteworthy. In South Africa, blooms appeared suddenly in 7 reservoirs in the 1990s (Van Ginkel and Silberbauer, 2006) - most prominently in Hartbeespoort Dam in 1999 (Van Ginkel et al., 2001). Parallel

\footnotetext{
* To whom all correspondence should be addressed.

용 +2733 260-5117; fax: +2733 260-5105; e-mail: hartr@ukzn.ac.za

Received 20 March2009; accepted in revised form 20 May 2009.
}

appearances were recorded in several reservoirs in Argentina in 1990, with northwards expansion to reach the neo-tropical Río Tercero Reservoir, also in 1999 (MacDonagh et al., 2005). Its appearance in the Paso de las Piedras Reservoir (Buenos Aires) in 1997 (Parodi et al., 2007) represents a broadly corresponding temporal profile. MacDonagh et al. (2005) suggest that its occurrence in the neo-tropics 'could be a regional phenomenon associated with some dispersal mechanisms and favourable local conditions for its proliferation', implying that this nuisance alga (see below) may become more widespread. The analysis of factor(s) underlying or stimulating its emergence becomes correspondingly important.

Reviewing the literature, Whittington et al. (2000) describe Ceratium hirundinella as a ubiquitous, relatively large and slow-growing species characteristically found during late summer, in water bodies with a warm stable epilimnion and low nutrient concentrations. Under these low-turbulence conditions, its ability to undertake significant diel vertical migrations (DVM) apparently enables its optimal exploitation of light and nutrients -2 essential resources whose availability contrasts directly in the vertical dimension during stratification (Heaney, 1976; Heaney and Furnass, 1980; James et al., 1992; 
Whittington et al., 2000). Seasonal periodicity of the species is, however, variable. Pérez-Martínez and Sánchez-Castillo (2001) reported clear winter maxima for an array of Spanish reservoirs, but subsequently (2002) further highlighted the variability of its occurrence reported in the literature. Notwithstanding its putative advantage at low nutrient levels (Whittington et al., 2000), Ceratium occurs in eutrophic lakes (e.g. Frempong, 1984), and was typified by Reynolds (Fig. 2 in Reynolds, 1996) as a component of late-summer phytoplankton associations in oligotrophic, mesotrophic and eutrophic (but not hypertrophic) temperate waters. In South Africa, Ceratium blooms have been recorded in 17 of 57 reservoirs, and were perceived as being 'serious' in 9 (Van Ginkel and Silberbauer, 2006). Among these reservoirs, blooms occurred in all seasons and across the trophic status range. Although most common in mesotrophic waters with total chlorophyll levels below $15 \mu \mathrm{g} / \boldsymbol{\ell}$, Ceratium blooms occurred in several waters of very high nutrient status, most prominently in the hyper-eutrophic Hartbeespoort Dam. Here, Ceratium was recorded for the first time in 1999 as a sudden-onset bloom that generated average chlorophyll levels of up to $600 \mu \mathrm{g} / \ell$ in the upper (0 to $5 \mathrm{~m}$ ) stratum (Van Ginkel et al., 2001), equivalent to cell densities of around 13500 cells/m $\boldsymbol{\ell}$ (see below). A subsequent rule-based model developed by Van Ginkel et al. (2007) to predict Ceratium abundance in various hypertrophic reservoirs in South Africa relies on prevailing nutrient concentrations (either TN and TP or SRP) as input drivers, further inferring nutrient enrichment as a causal/contributory factor underlying bloom occurrence, in contrast to a previous perception of Ceratium as an 'indicator' species of 'clean' water (e.g. Padisák, 1985; Buck and Zurek, 1994).

Ceratium is recognised as a problem alga on 2 counts; it imparts tastes and odours to potable water, and clogs water purification filters. The sudden onset of blooms recorded in 7 reservoirs (Van Ginkel and Silberbauer, 2006), and described in detail for Hartbeespoort Dam (Van Ginkel et al., 2001), is accordingly very significant in terms of water quality management. But it is also commensurately intriguing from a purely ecological perspective. Ecosystems often respond abruptly to gradual changes in forcing variables, and can exhibit unexpected discontinuous shifts to an alternative state as the ecosystem exceeds a threshold in one or more of its key variables or processes. Underlying ecological thresholds define conditions beyond which an abrupt change in a quality, property, or phenomenon of the ecosystem may occur (Groffman et al., 2006). Such changes, commonly human-induced, can lead to sudden, unexpected switches to 'new' alternative ecological states, which are commonly less desirable with respect to ecological services valued by society. The identification of such ecological thresholds promises to reveal much about mechanistic functioning of community processes and also has direct implications for resource management.

The extensive re-structuring of plankton communities (both autotroph and zooplankton components) associated with emergent blooms of Ceratium can be broadly likened to a change of state, which, while perhaps 'unstable', is otherwise loosely analogous to switches between hydrophyte- and algaldominated shallow lakes (e.g. Moss, 1998). Here, we describe the sudden appearance of Ceratium at bloom densities in Albert Falls Dam (plausibly reflecting the transcendence of an ecological threshold) and attempt to evaluate the likely causality and ecosystem consequences of this 'new dimension' in an 'old' (mature) reservoir of paramount strategic importance in a water-scarce nation.

\section{Study area, context and questions}

The Mgeni catchment, covering roughly $4000 \mathrm{~km}^{2}$ of central KwaZulu-Natal, South Africa, serves as a crucial water source for the Greater Durban and Pietermaritzburg Metropolitan areas. Roughly $45 \%$ of the province's population occupies this region, which accounts for some $20 \%$ of South Africa's gross national product (Keinzle et al., 1997). With such concentrated economic activity, an assured supply of potable water and the maintenance of good water quality represent major challenges. Water quality monitoring remains paramount to identify any manifestation of declining water quality, ahead of objective logical scrutiny and critical evaluation of causes, consequences, prognoses, and prospective mitigation interventions.

Water quality naturally and inevitably declines progressively downstream along the Mgeni River reservoir cascade (Fig. 1). However, at least the upper 2 reservoirs - Midmar and Albert Falls Dams - remained mesotrophic (or better), with no obvious deterioration in water quality before 1998, when a contemporary phase of zooplankton and associated limnological research work was terminated (Hart, 2001; 2004; 2006). Up to this time, no significant algal blooms had manifested in these reservoirs (Hart 2006), in keeping with the low P pollution potential modelled for their respective local catchments (Keinzle et al., 1997). No adverse changes in water quality status were (publicly) reported from the ongoing routine water quality monitoring of key chemical and algal variables by Umgeni Water, the parastatal authority with dedicated responsibility for management of water resources and associated infrastructures in the Mgeni catchment.

Against the above background, the detection of a major dinoflagellate bloom during a multi-site synoptic survey of Albert Falls, fortuitously undertaken as a student-training exercise, in October 2006 was entirely unexpected, and stimulated the more comprehensive investigation and analysis reported herein. We sought answers to and/or explanations for the following questions.

- Would the bloom persist in time, and spatial extent? A repeat synoptic survey of Albert Falls was undertaken in high summer (January 2007). The findings of this led in turn to fine-scale spatial investigation of dinoflagellate distribution in the river inflow and discharge plume regions of the lake.

- Was this seemingly unprecedented/novel bloom occurrence related to implementation of the Mooi-Mgeni inter-basin water transfer scheme in 2004? A survey of Midmar Dam was undertaken immediately after the bloom was encountered in Albert Falls in October, to determine conditions in this upstream feeder reservoir, through which the Mooi River transfer feeds into the Mgeni system (Fig. 1).

- Was there any historical precedent to the 2006 bloom in Albert Falls? Umgeni Water archival water quality records were accessed and examined for relevant evidence.

- What underlying causal factors or drivers could account for the bloom in Albert Falls? Historical water quality variables were examined, as outlined for the previous question. This question is especially pertinent given the recent and/ or sudden appearance of Ceratium blooms during the past decade in other South African reservoirs (Van Ginkel and Silberbauer, 2006; Van Ginkel et al., 2001; 2007) and elsewhere abroad.

- What direct $1^{\text {st }}$-order impacts did the bloom exert on structural and functional attributes of the Albert Falls ecosystem? Two tangible candidates for examination were 


\section{Figure 1}

Map of the Mgeni River reservoir cascade, showing its location in South Africa (lower left), with enlarged outlines (upper) of its upstream reservoirs, marked to show synoptic survey sites on Albert Falls and Midmar used during this study. Points labelled A indicate approximate position of historical reference sampling sites. Scale bar represents $2 \mathrm{~km}$ on the enlarged reservoir outlines, which are at the same scale.

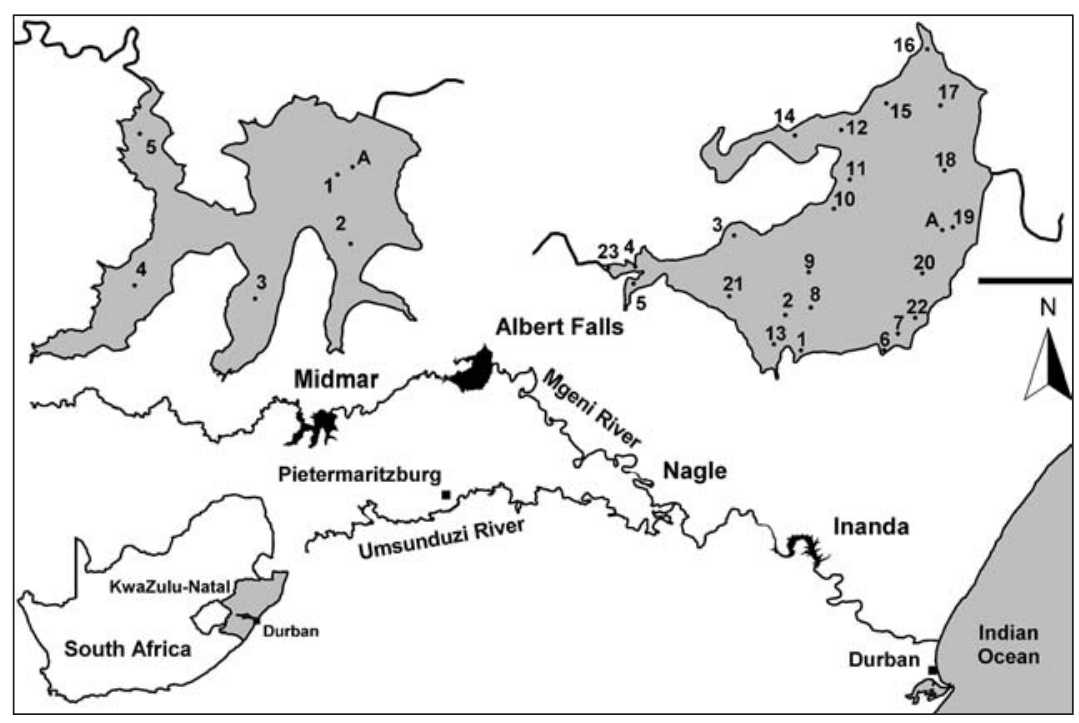

immediately obvious. First; changes in vertical oxygen profiles resulting from the metabolic activity of living algae, and prospects of subsequent severe de-oxygenation following collapse and decomposition of the bloom, with associated rapid and vertically extensive hypolimnetic de-oxygenation, and possible fish kills, were plausible. Second; by virtue of its large size and 'armouring' horns, Ceratium is effectively immune to grazing by microphagous zooplankton. Changes in zooplankton composition following the algal shift to this inedible dinoflagellate were accordingly investigated by reference to historical records (Hart, 2000; 2001; 2004; 2006, and unpublished records).

- Can answers to the question regarding underlying causal factors provide for any objective future prognosis, and perhaps identify ecologically appropriate mitigation measures?

\section{Methods}

Sampling sites for the synoptic survey (see Fig. 1), undertaken on 7 to 8 and 14 to 15 October 2006, were chosen to provide representative coverage of open-water, back-water and inflow reaches of the reservoir, as well as a range of site distances from the nearest shoreline. Following discovery of the bloom reported here, the synoptic survey was repeated on 22 January 2007 , leading in turn to a spatially finer-scale survey of the Mgeni River inflow and discharge plume on 24 January 2007. Site co-ordinates were determined with a Garmin Model 60 portable GPS.

Vertical profiling of temperature and dissolved oxygen (DO) was undertaken at $1 \mathrm{~m}$ intervals from the lake surface to the bottom of the water column $(\leq 15 \mathrm{~m})$ with an electronic YSI Model 56 Temperature/DO meter. In situ profiling of total chlorophyll, and its relative partitioning between greens, bluegreens, cryptophytes and diatoms (三Ceratium - see below) was undertaken at $1 \mathrm{~m}$ intervals from $0 \mathrm{~m}$ to $5 \mathrm{~m}$ depth, using a bbe Moldaenke Submersible Fluoroprobe Spectrofluorometer. Subsurface samples $(50 \mathrm{~m} \ell$ ) of water were collected concurrently with most subsurface fluoroprobe readings and preserved on site (with Lugol's iodine) for subsequent laboratory enumeration of dinoflagellate densities. Secchi depth transparency was measured in shade (where possible) with a $22.5 \mathrm{~cm}$ diameter white disk.

Zooplankton was collected in vertical net hauls from roughly $1 \mathrm{~m}$ above bottom to the surface, using a conical

\begin{tabular}{|l|c|}
\hline \multicolumn{2}{|c|}{ TABLE 1 } \\
Coefficients used to convert zooplankton numbers to \\
biomass. As the conversions disregard sample-specific \\
body size distributions, the derived biomass estimates \\
are used only to provide a comparative integrative \\
measure of abundance - permitting visualisations of \\
spatial distribution patterns.
\end{tabular}

Nansen-type net with a reducing cone, mouth diameter of $25 \mathrm{~cm}$ and mesh pore aperture of $53 \mu \mathrm{m}$. Samples were preserved in the field with formalin. Prior to enumeration, samples were washed through $160 \mu \mathrm{m}$ mesh to reduce the obscuring and smothering effects of Ceratium. Our analysis was thus primarily restricted to macro- and meso-zooplankton. Samples were standardised to $50 \mathrm{~m} \boldsymbol{\ell}$, generally with 4 replicate $1 \mathrm{~m} \boldsymbol{\ell}$ sub-samples thereof being enumerated. Counts were converted to biomass using coefficients specified in Table 1. The 'herbivore' biomass fraction comprised all zooplankton excluding Chaoborus (generally an obligate carnivore - but see Xie et al., 1998) and part (1/3) of the cyclopoid copepod component, a fractional allocation based on the mixed functional role of cyclopoid copepods as herbivores and carnivores in different species and/or life history stages (e.g. Hansen and Santer, 1995; Brandl, 1998). Further analytical protocols are detailed elsewhere (Hart, 2001; 2004).

Assuming a uniform biomass (or density) per unit volume through the water column, biomass or density per unit area will obviously increase with water depth (haul length); conversely, average biomass or density per unit volume is likely to decline as water depth increases. To counter these inevitable biases, 


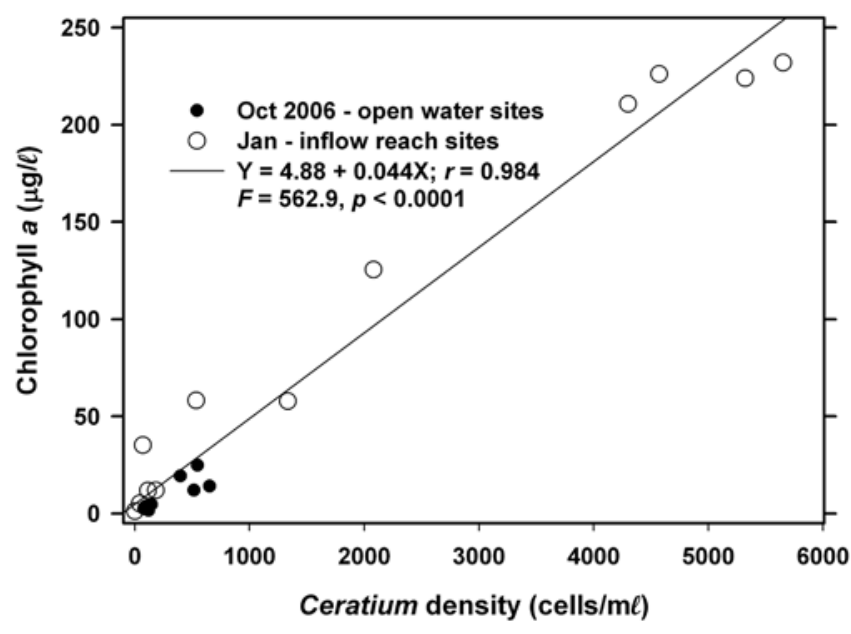

Figure 2

Chlorophyll a concentration in relation to Ceratium cell density in open water synoptic survey sites during October, in inflow and discharge plume sites in January, and the overall regression relationship.

zooplankton abundance and biomass over the lake at large (during the synoptic surveys) is reported both in areal $\left(/ \mathrm{m}^{2}\right)$ and volumetric $\left(/ \mathrm{m}^{3}\right)$ terms. Numerical abundance values are used in preference to the corresponding derived biomass estimates, wherever appropriate.

Cross-calibration of Ceratium densities (X) with fluoroprobe values (Y) of 'diatom' chlorophyll at sites sampled on the $2^{\text {nd }}$ day of the October survey provided unambiguous evidence that the dinoflagellate was recorded as 'diatom' chlorophyll $(\mathrm{Y}=79.03+22.71 \mathrm{X}, \mathrm{r}=0.840, \mathrm{n}=9, \mathrm{p}<0.001)$; genuine diatoms were barely evident in concurrent samples. Furthermore, it is clear that 'total' chlorophyll values are almost completely accounted for by corresponding Ceratium densities across the full range of values encountered during both synoptic surveys (Fig. 2). Accordingly, as and where appropriate in the following account, chlorophyll is used as a direct proxy for Ceratium density.

Lake-wide patterns of chlorophyll concentration and zooplankton biomass were interpolated from the synoptic survey site values and mapped. Using ArcView 3.3, the common use practice of estimating values at each map pixel as a weighted average of the values at a subset (12 in this case) of nearest sampling stations, each station being weighted by the reciprocal of its cubed distance from that point, was employed. Peninsulas were treated as barriers, so that sampling stations in inlets could influence interpolated values only according to their separation distance over water (around the peninsulas), not their distance over land.

Umgeni Water's archival database of an array of chemical water quality variables and algae routinely monitored in the Mgeni River at its inflow into Albert Falls Dam (Site RMG008) and at an offshore site in the Dam (DAF001 and DAF003) provide an historical record against which to examine the changes reported here.

The last major drought in 1995 was selected as a starting year for this examination. This database reflects a changed monitoring frequency - roughly weekly from 1995 to 2001, and thereafter fortnightly (2002 to 2007), with only monthly values for the inflow site from 2005. A variable (but rising) number of values are reported as assay limits $(<3 \mu \mathrm{g} / \ell,<15$ $\mu \mathrm{g} / \ell$ and $<0.05 \mathrm{mg} / \ell$ for SRP, TP and $\mathrm{NO}_{3}-\mathrm{N}$ respectively), rather than as absolute values. To avoid inflating calculated mean values, these records were not merely excluded, but were applied literally (as 3, 15 and 0.05 ). Without $\mathrm{TN}$ values, the N:P values reported here are surrogate ratios based on $\mathrm{NO}_{3}-\mathrm{N}: \mathrm{TP}$. Nutrient loads for Albert Falls were calculated as the product of total monthly inflows (M $/$ month) and monthly mean nutrient concentrations of inflow waters, based on between 1 and 4 recorded values per month. In a few cases where no nutrient values were available for the calendar month, an average value interpolated from the straddling months was applied.

Overall statistical analysis of these data (using Statistica 98) was constrained by the limited temporal co-incidence of time series records, especially in recent years when Ceratium was common. For instance, correlation matrices of Ceratium abundance, nutrient concentrations, and estimated water column stability (based on concurrent vertical temperature profiles) cannot be calculated. Causality of the Ceratium blooms accordingly remains largely subjective inference.

Zooplankton abundance and community composition during the 2006/07 Ceratium bloom was compared with that of previous years. For each taxon, the average density at the 3 open-water stations (Sites 18 to 20, Fig. 1, hereafter identified as DOWS - deep open water sites) nearest the long-term monitoring site (Station A, Fig. 1) was compared with 'historical' sample values collected and analysed (using the same protocols reported here) at the closest corresponding date (in October and January) each year from 1989 to 1998 at Station A (Hart, 2000; 2001; 2004). For some comparisons, historical average values excluding years of high mineral turbidity (temporally congruent Secchi depth values $\leq 100 \mathrm{~cm}$ ) were used.

Community composition was summarised using nonmetric multidimensional scaling (NMDS) based on BrayCurtis dissimilarity, implemented in the $\mathrm{R}$ package vegan (Oksanen et al., 2008). The meta-MDS function was used to find stable NMDS solutions by checking that different random starting points converged on the same ordination. Before analysis, each density value was divided by the maximum density in any year for that species, and then by the maximum density of any species for that year (procedurally termed Wisconsin double standardisation) to ensure that uncommon species and years of generally low density were given the same weight as more abundant species and more productive years.

\section{Results and discussion}

\section{Horizontal and vertical distribution patterns of chlorophyll and Ceratium in Albert Falls}

Synoptic surveys revealed considerable spatial variation in total chlorophyll content (as a site mean of the 0 to $5 \mathrm{~m}$ profile), and the associated abundance of dinoflagellates. In October (Fig. 3a), chlorophyll showed a clear west-east gradation along the hydraulic axis of the lake, with distinctly higher values associated with the Mgeni River inflow. Values exceeded $10 \mu \mathrm{g} / \boldsymbol{\ell}$ ( $\equiv>220 \mathrm{cells} / \mathrm{m} \boldsymbol{\ell}$ of Ceratium) over roughly a third of the lake area, yielding a lake-wide station average of $11.7 \mu \mathrm{g} / \ell$. While chlorophyll values were distinctly and significantly lower over most of the lake in January (Fig. 3b; Wilcoxon matched-pairs test using the 19 stations sampled in both months: $p=0.018$ ), substantially higher values in the Mgeni inflow region inflated the overall January lake average to $16.4 \mu \mathrm{g} / \ell$. Intensive sampling of the inflow region, undertaken shortly after this synoptic survey, revealed an astonishingly abrupt appearance of Ceratium in the lake, and its general 
Figure 3

Spatial distribution of average chlorophyll concentration $(\mu \mathrm{g} / \mathrm{l})$ in the 0 to $5 \mathrm{~m}$ stratum in Albert Falls Dam in October 2006 (a) and January 2007 (b). Points correspond to sampling stations numbered in Fig. 1.
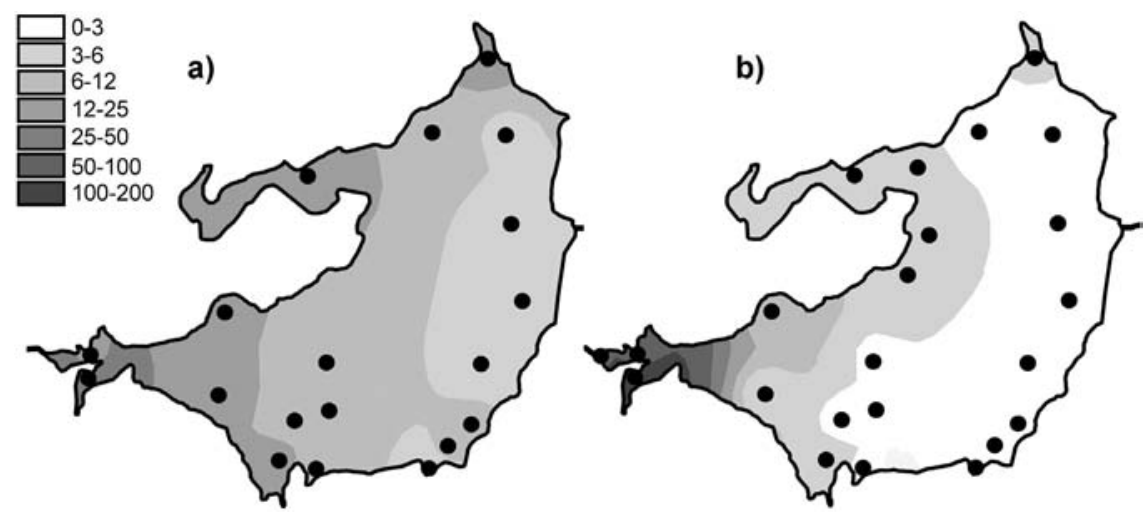

a)
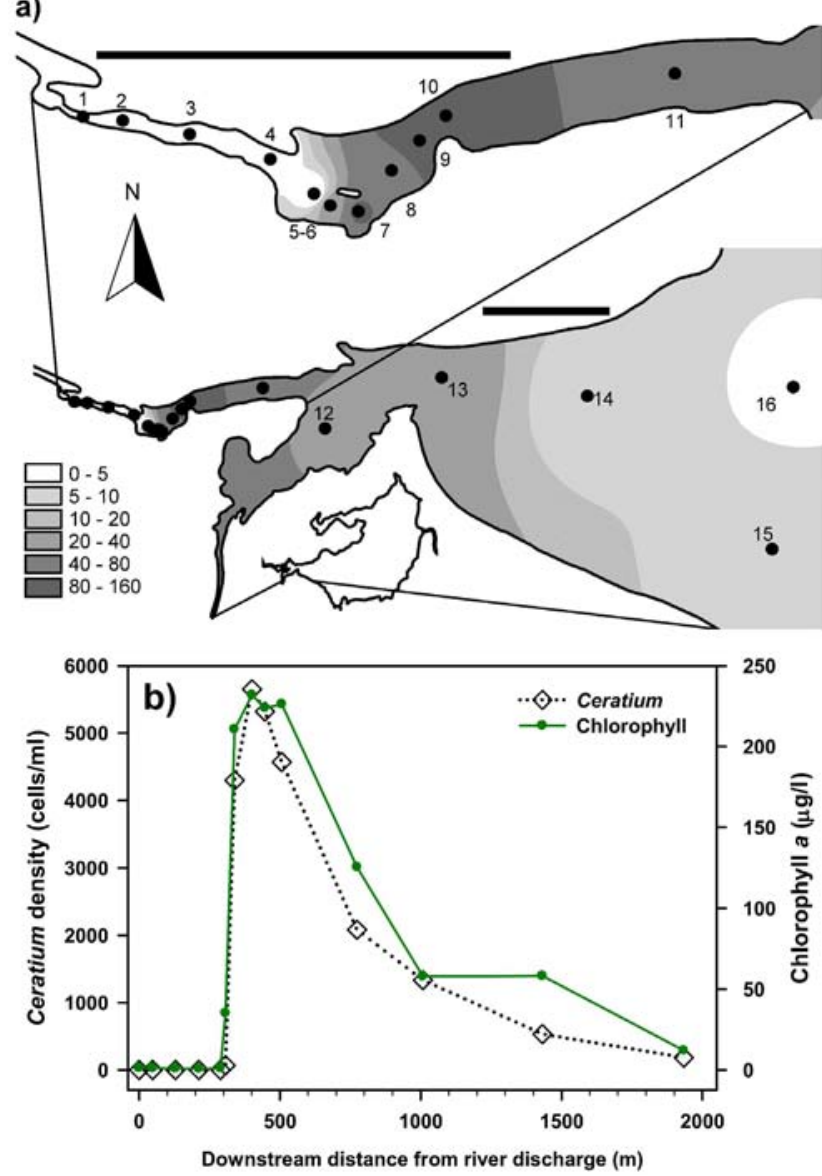

Figure 4

(a) Spatial distribution of average chlorophyll concentration $(\mu \mathrm{g} / \mathrm{l})$ in the 0 to $5 \mathrm{~m}$ stratum in the inflow plume of Albert

Falls Dam in January. Numbered points indicate the position of sampling stations. Both scale bars represent $0.5 \mathrm{~km}$.

(b) Scatter plot of chlorophyll and Ceratium density (actual counts, not regression estimates) in relation to distance from the Mgeni River inflow.

dissipation along the inflow plume (Fig. 4). While the influent river flow was virtually devoid of autotrophs (chlorophyll $\leq 1 \mu \mathrm{g} / \boldsymbol{\ell}$ ), Ceratium density rose from 0 to over 5000 cells $/ \mathrm{m} \boldsymbol{\ell}$ over a distance of barely $100 \mathrm{~m}$ (Fig. 4b); this abrupt increase spatially coincided with the lake-side edge of a roughly 15 to $20 \mathrm{~m}$ wide band of water lettuce (Pistia stratiotes) spanning the influent river channel (Fig. 5).

Broadly consistent increases in chlorophyll with depth, indicative of 'deep-water' chlorophyll maxima, were evident

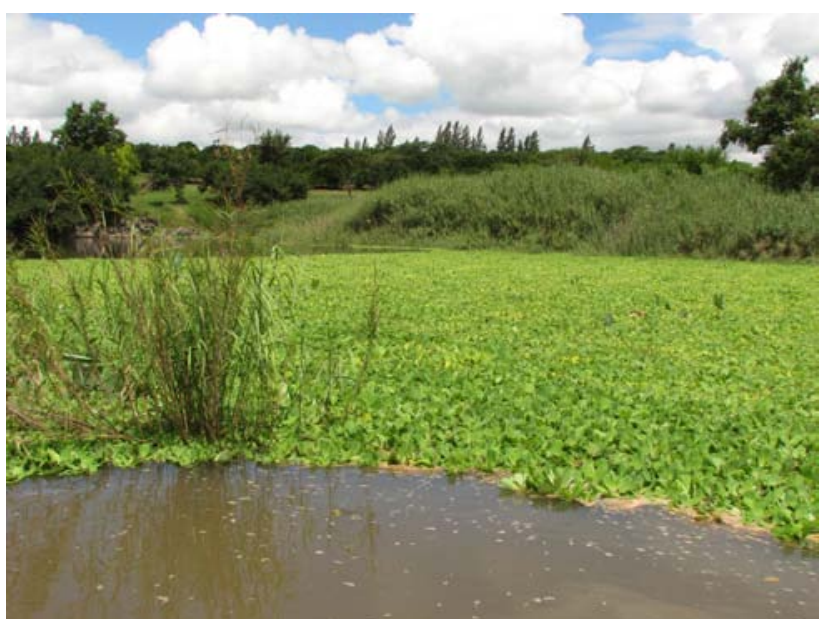

Figure 5

Downstream view over a Pistia stratiotes mat below the Mgeni River inflow into Albert Falls Dam that effectively demarcated the river-dam confluence, and below which Ceratium density increased rapidly - as shown in Fig. $4 b$.

both in October and January. The effect of averaging widely disparate values that existed between individual sites (see Fig. 3) masks this feature in plots of mean depth vs specific absolute chlorophyll values (Fig. 6a), but it is clearly revealed in corresponding plots of mean depth vs. specific relative values (Fig. 6b). (Here, 'relative' values refer to vertical values as a percentage of individual column profile maxima; by way of example, absolute values of 10,15 and $20 \mu \mathrm{g} / \ell$ at successive depths yield a relative profile of 50, 75 and $100 \%$.) In this context, the existence of chlorophyll levels at $5 \mathrm{~m}$ averaging nearly twice the surface values in both months over the entire lake (Fig. 6b) parallels other records of Ceratium-generated deep-water chlorophyll maxima (e.g. Grigorszky et al., 2003). But in contrast with the chlorophyll increase with depth in both synoptic surveys, both absolute and relative values in the inflow plume declined strongly with depth (Fig. 6), in line with light-limitation imposed by elevated levels of suspended solids. Secchi depth transparency averaged only $53 \mathrm{~cm}$ in the influent river, $104 \mathrm{~cm}$ in the river plume, and $215 \mathrm{~cm}$ over the lake as a whole in January (vs. $256 \mathrm{~cm}$ in October). With the fluorometer's chlorophyll profiling limit of $5 \mathrm{~m}$, it was not possible to establish the full extent or vertical profile of Ceratium distribution, nor evaluate thermal influences thereon. Concurrent thermal profiles during the synoptic surveys (Fig. 7) suggest an inverse relationship with temperature, but the absence of Ceratium data in deeper water $(>5 \mathrm{~m}$ ) precludes any 

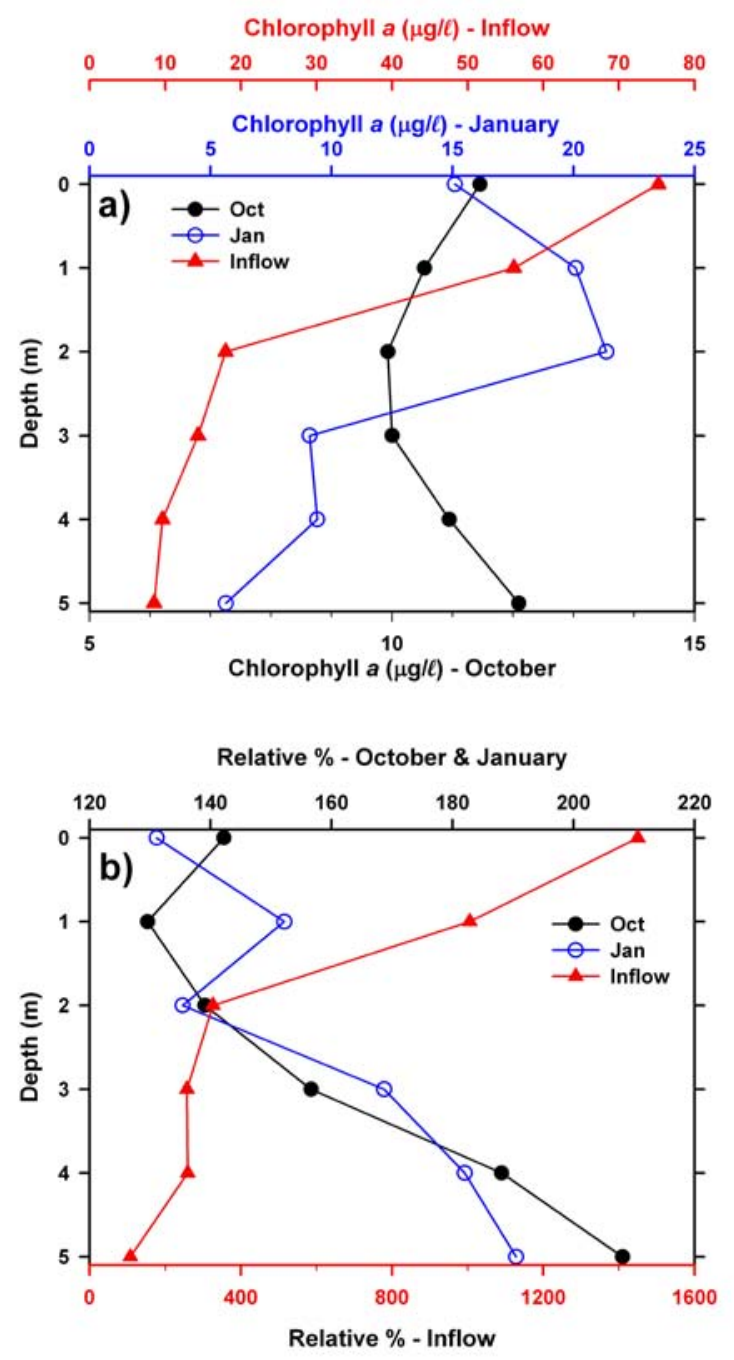

Figure 6

a) Vertical profiles of lake-wide average chlorophyll concentrations (absolute) in October and January, and in the inflow plume region in January.

b) Corresponding relative profiles (see text) for lake-wide surveys show deep water chlorophyll maxima. Note different axis scaling.

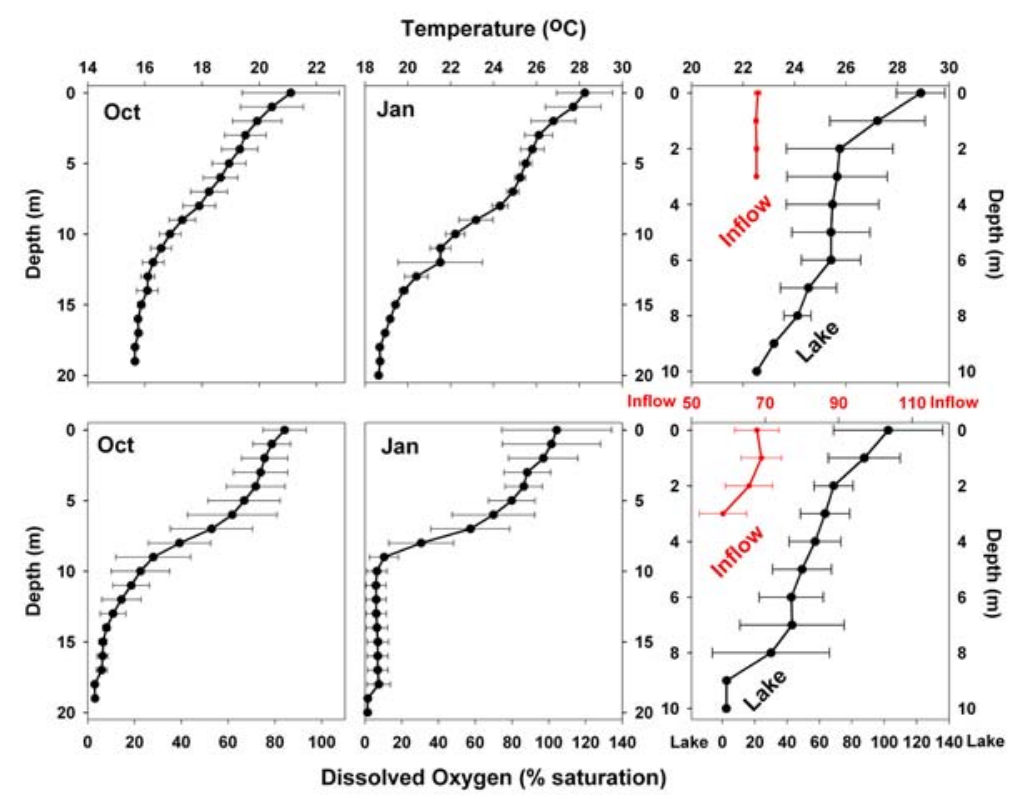

Available on website http://www.wrc.org.za distinction between temperature and light intensity as determinants of the dinoflagellate's vertical distribution. Both variables have previously been implicated as controlling factors (e.g. Whittington et al., 2000; Talling, 2004). In this study, Ceratium density (inferred from diatom chlorophyll) across all depths at offshore sites $10 \mathrm{~m}$ or deeper correlated negatively both with temperature (correlation coefficients of $-0.33 *$ in October, $-0.32^{\text {ns }}$ in January), and with dissolved oxygen saturation levels (with corresponding coefficients of $-0.13^{\text {ns }}$ and $-0.395^{* *}$ ). This inverse Ceratium-oxygen relationship indicates that vertical depletion in oxygen (Fig. 7) may be largely attributable to dinoflagellate metabolism, especially in January, highlighting Ceratium's potential impact on water column de-oxygenation. Partial correlation analysis, controlling for thermal influences on the Ceratium-oxygen relationships, strongly supports this inference for the January data (partial correlation coefficient of $\left.-0.343^{* *}\right)$, although the corresponding coefficient for October (0.137) was not significant.

Indications of diel vertical migration by Ceratium are reflected in diurnal changes in vertical chlorophyll profiles in October (Fig. 8a). A surface accumulation of cells in the early morning declined notably during the solar azimuth, leading to a subsurface chlorophyll maximum (at $2 \mathrm{~m}$ ). By late afternoon, peak values were again established in surface waters. These changes were essentially independent of the corresponding diurnal changes in thermal regime (Fig. 8b), and most probably reflect migratory movements 'designed' to track optimal light levels, often well below the surface (e.g. Heaney and Furnass, 1980; Whittington et al., 2000).

\section{Concurrent conditions in Midmar Dam}

Corresponding profiles at strategic sites in Midmar (Fig. 1), undertaken 2 days after the initial discovery of the bloom in Albert Falls, revealed no evidence of Ceratium blooms. Conversely, chlorophyll values were astonishingly low, ranging between 1.45 and $1.76 \mu \mathrm{g} / \boldsymbol{\ell}$ (average $=1.6 \mu \mathrm{g} / \boldsymbol{\ell}$ ), with commensurate main basin water transparency levels at virtually unprecedented highs (Secchi depth range $=4.0$ to $5.3 \mathrm{~m}$, average $=4.7 \mathrm{~m}$ ) compared to historical records (e.g. Hart, 2006). Ceratium was present but very sparse in zooplankton net samples from Midmar, indicating its occurrence at a
Figure 7

Lake-wide mean ( \pm SE) vertical profiles of temperature and dissolved oxygen during October and January synoptic surveys, and corresponding January values in the river inflow and discharge plume in the lake. 
virtually undetectable density in un-concentrated water samples. This effectively excludes inter-basin transfers (IBT) from the Mooi River as a direct causal agent of blooms in Albert Falls. In any event, this alga was present in Albert Falls before the IBT was implemented (see below), and explanations for its development to bloom levels in Albert Falls must be sought 'closer to home'.
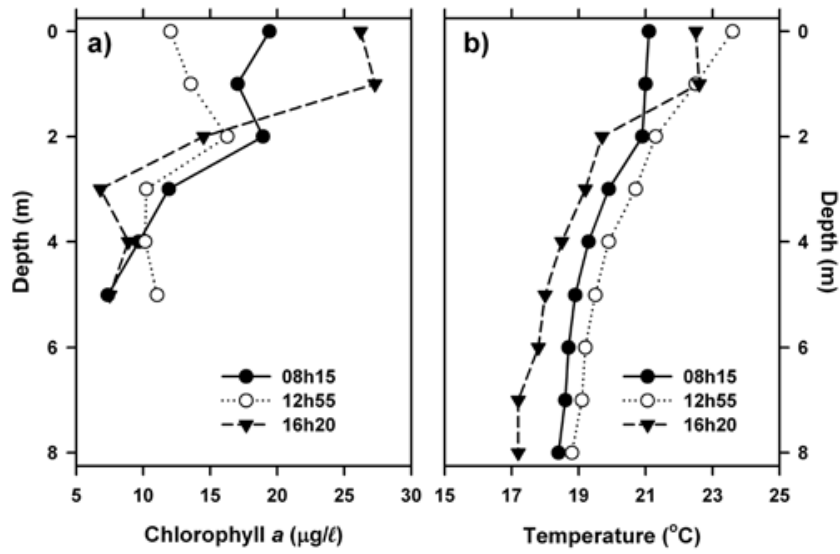

Figure 8

Diurnal temporal changes in a) chlorophyll and b) temperature at an inshore station (Site 14) in Albert Falls Dam in October.
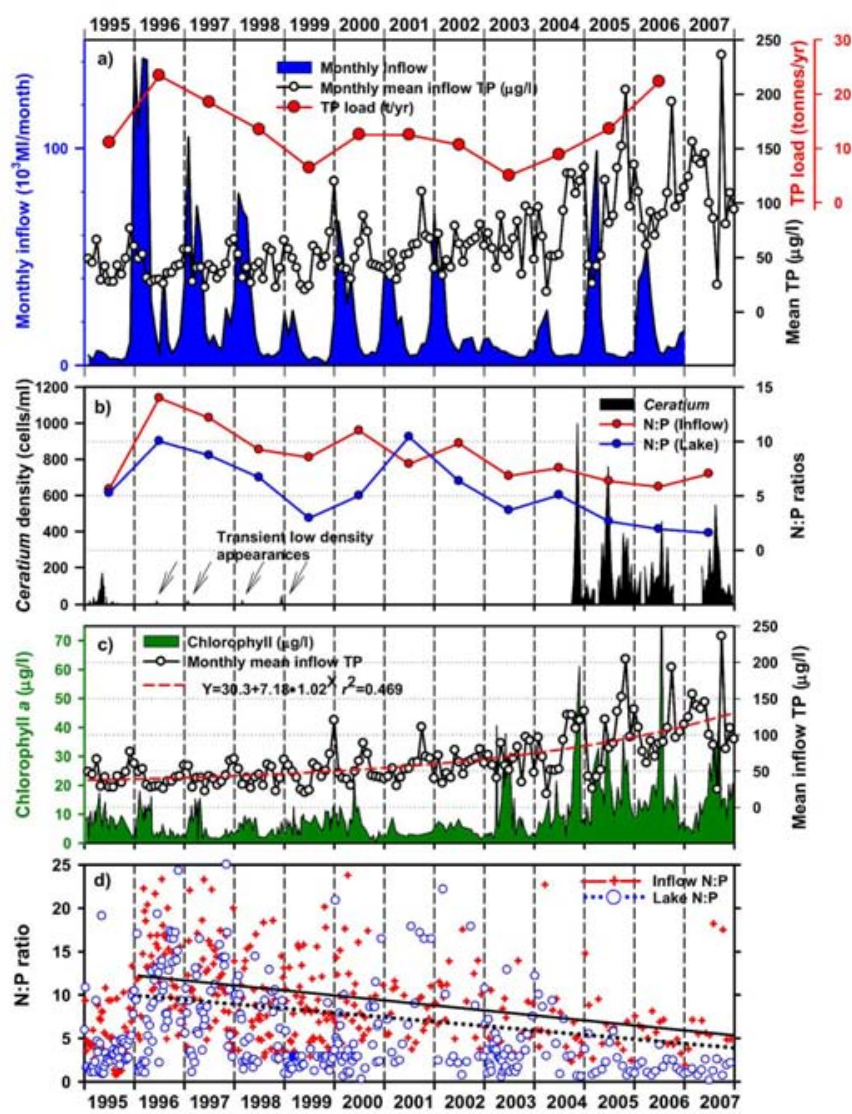

Figure 9

Long-term profiles of a) Albert Falls inflow volumes, monthly and annual TP loads; b) Ceratium abundance in relation to mid-lake and inflow N: P ratios; c) mid-lake chlorophyll concentrations in relation to monthly mean TP values of inflow water (with fitted regression, where $X$ is time in months since January 1995);

d) comparative $N$ : $P$ ratios in inflow and mid-lake waters.
Historical precedents to bloom levels of Ceratium in Albert Falls Dam

Inspection of Umgeni Water archival data (Fig. 9) revealed low-density occurrences of Ceratium in 1995 (Fig. 9b), and transient appearances in the following 4 years, preceding an extremely abrupt and unprecedented outburst in 2004 (Figs. 9b and 11a). Similar pre-emptive low-density occurrences in 1992 and 1993 were reported by Hart (2006). Since dinoflagellate densities at a routine main basin sampling site in Albert Falls (A on Fig. 1) were considerably greater in 2004 (Fig. 11a) than those we encountered in 2006/2007, concurrent densities in the Mgeni inflow region in 2004 can only be imagined. The appearance of any bloom of such severity presumably invoked concern and diagnostic attention by the responsible parastatal water authority, but received no open publicity.

\section{Underlying causal drivers of Ceratium blooms}

Any unprecedented and/or abrupt appearance of a species, and especially its attainment of high densities, clearly manifests some ecological change or switch, or the surpassing of some ecological threshold. Historical water quality records (Figs. 9 and 10) point irrefutably to progressive nutrient enrichment as a contributory or direct causal factor. Nutrient concentrations in lake inflow waters have increased inexorably from 1995 (Fig. 9a), with mean annual inflow nutrient concentrations (Fig. 10a) rising most strongly for SRP (3.6-fold), but also for TP (2.8-fold) and $\mathrm{NO}_{3}$-N (2.2-fold). Calculated annual P loadings have also risen (Fig. 9a), albeit less markedly. Data for total $\mathrm{N}$ levels are unfortunately not available. Broadly parallel increases in SRP and TP levels were evident in the lake itself as in its inflows, especially from 1996 (Fig. 10b), although
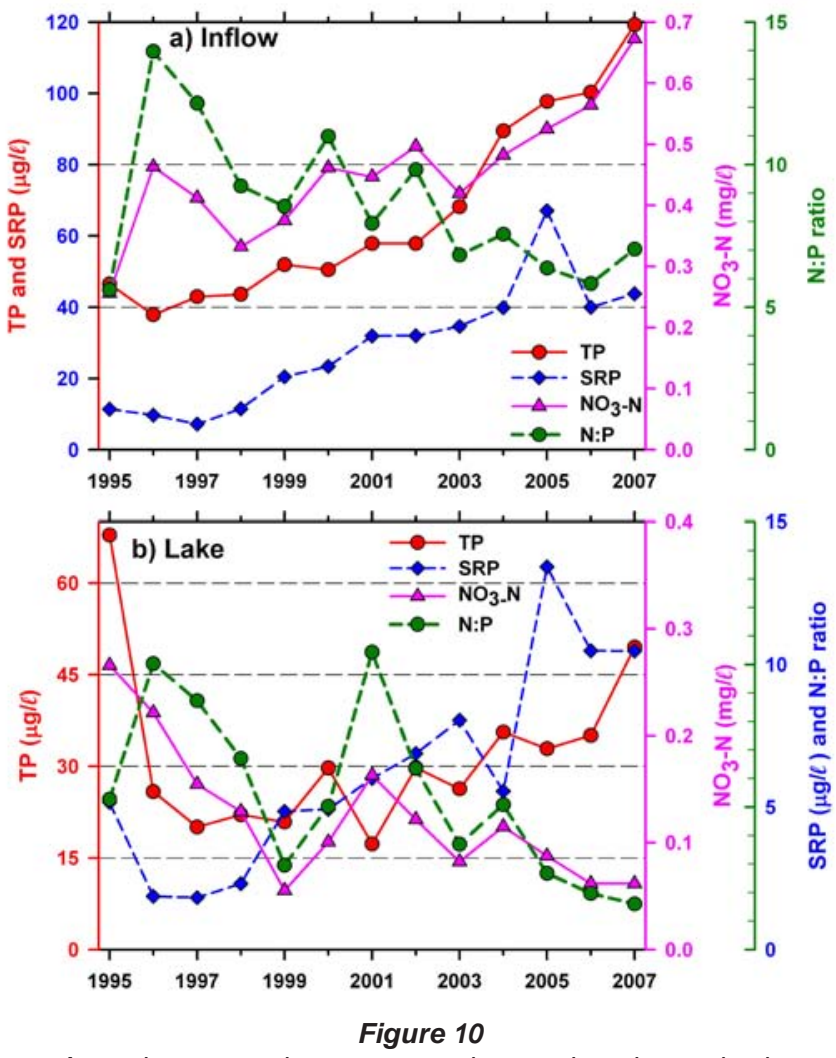

Annual mean nutrient concentrations and nutrient ratios in a) inflow water and b) mid-lake region of Albert Falls. 


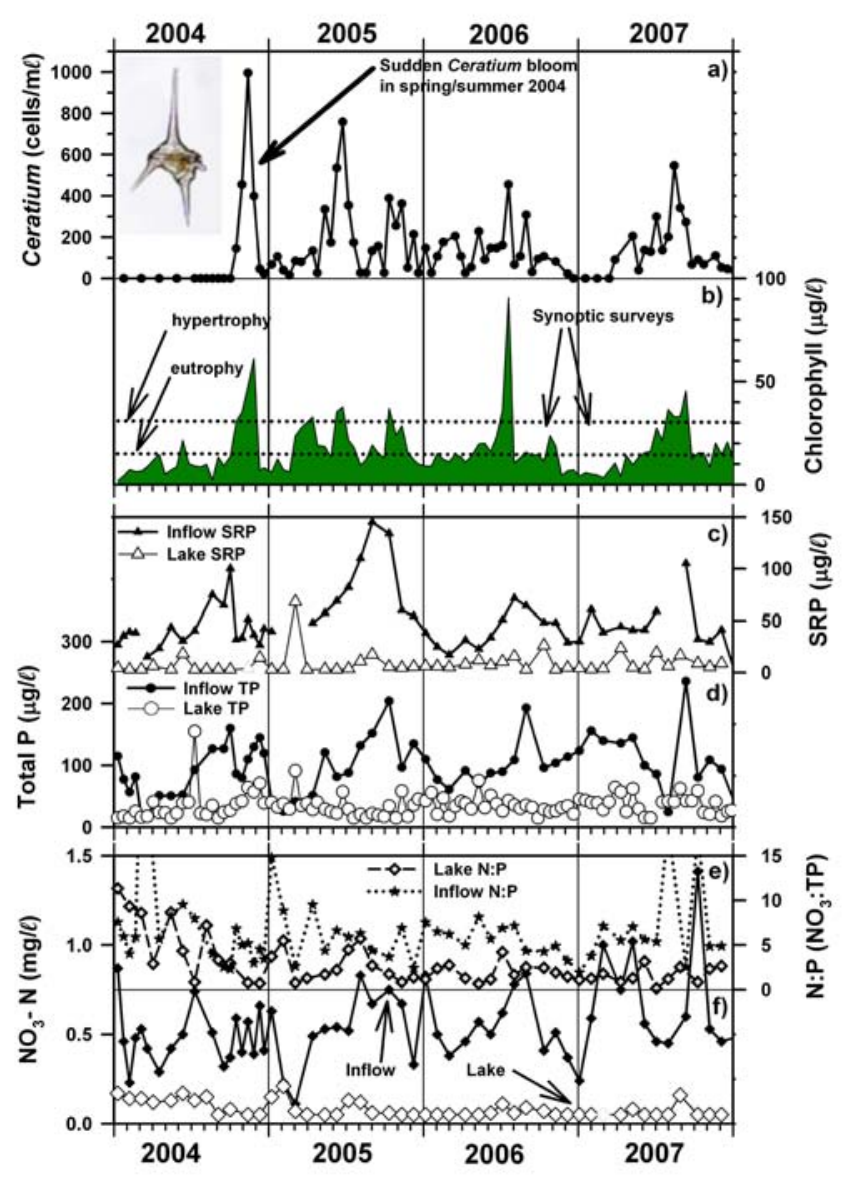

Figure 11

Seasonal periodicity of a) Ceratium and b) corresponding chlorophyll levels (showing conventional higher trophic status limits) in Albert Falls since the appearance of this dinoflagellate at bloom density levels in late 2004, in relation to concurrent inflow and in-lake levels of c) SRP; d) TP; and corresponding e) N: $P$ ratios; and f) $\mathrm{NO}_{3}-\mathrm{N}$ levels.

the magnitude of increase in the lake was lower, undoubtedly reflecting dilution effects and in situ buffering and assimilative mechanisms.

The initial presence of Ceratium in 1995 coincided with the highest mean annual TP levels (nearly $70 \mu \mathrm{g} / \ell$ ) in this data set and N:P values of $\sim 5$, while its 're-appearance' in 2004 and subsequent persistence were also commensurate with TP levels $\geq 30 \mu \mathrm{g} / \ell$ and $\mathrm{N}: \mathrm{P}$ values $<5$ (Figs. 9b and 10b). Despite extreme variability in $\mathrm{N}: \mathrm{P}$ values (perhaps exaggerated by analytical artefacts), it is clear that the N:P ratio both in the inflow and the lake declined progressively from 1996 (see trend lines in Fig. 9d), to annual averages in 2004 of $\sim 7.5$ in the inflow and $\sim 5.5$ in the lake - declines which have subsequently continued (Fig. 10). These reductions in N:P reflect faster increases of $\mathrm{P}$ than $\mathrm{N}$ concentrations in inflow waters, rather than reductions in N (Fig. 10a). The P source is most plausibly attributable to effluent from the Howick Wastewater Treatment Plant - urbanisation having been the major development in this catchment.

\section{Ceratium periodicity in Albert Falls}

The inconsistent and/or contradictory pattern of seasonal occurrence in Ceratium between lakes was identified in the Introduction. Figure 11a reflects corresponding variability in its periodicity (at a single deep-water offshore site) within
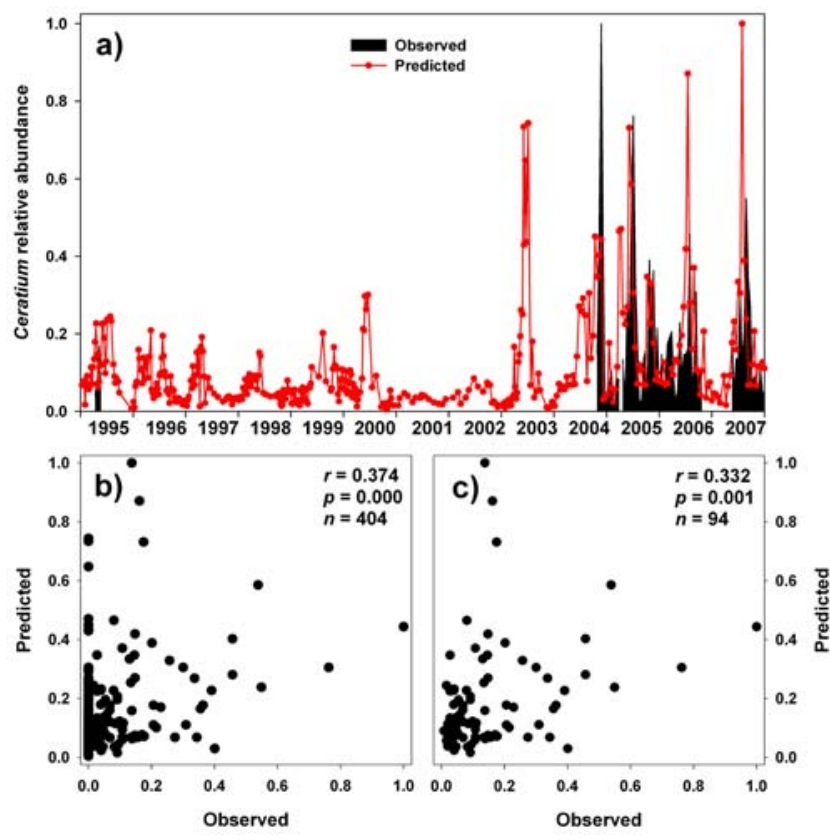

Figure 12

Predicting Ceratium abundance in Albert Falls with a rule-based model. a) Observed vs. predicted time-sequence values between 1995 and 2007, with comparative observed vs. predicted scatter plots: b) for the entire time sequence, including the prolonged initial period of Ceratium absence; and c) for periods when Ceratium was actually present.

a single water body - Albert Falls. The first major bloom of Ceratium in 2004 was an early summer outbreak. Although present throughout the year in 2005, suggestions of an underlying annual bimodality nonetheless exist; Ceratium showed a major peak in early winter and a subsequent increase in late spring/early summer. While no obvious peaks were evident in 2006, weak suggestions exist of its increase in early spring. In 2007, peak densities were reached in early spring. Collectively over these 4 years, the underlying phenology displayed by Ceratium is indicative of a temporal association with periods of instability or circulation. Its consistent absence or sparseness in mid-summer is congruent in this regard. However, statistical evaluation of such perceived correlations was unfortunately not possible, for reasons explained in the Methods. But overall, the general temporal trend exhibited in Albert Falls is somewhat at variance with its placement as a late-summer component in the seasonal associations described for temperate waters by Reynolds (1996); this reinforces the conclusion by Pérez-Martínez and Sánchez-Castillo (2002) that 'The factors that govern the seasonal distribution of $C$. hirundinella have yet to be fully elucidated'. With its sudden appearance at bloom densities, and its impact on potable water supplies, better resolution of this problem is clearly warranted. The following section explores potential advances in this respect.

\section{Transferability of an external prediction model of dinoflagellate abundance}

A rule-based 'hybrid evolutionary algorithm' model to predict Ceratium abundance (as biomass volume) in hyper-eutrophic reservoirs was developed by Van Ginkel et al. (2007). While models of this type require 'training' for local conditions to yield effective predictions, we casually tested the model's transferability to the vastly different nutrient arena of Albert Falls 
Dam without appropriate 'training'. For Albert Falls, where chlorophyll levels (Chl a) remain below $190 \mu \mathrm{g} / \ell$, the ELSE rule of the model (Van Ginkel et al., 2007) predicts dinoflagellate biomass (DinoBiomass $-\mathrm{cm}^{3} / \mathrm{m}^{3}$ ) as:

$$
\text { DinoBiomass } \left.\left.=\left(\left(\text { Chl a/(( } \mathrm{T}_{\text {surf }} * 0.662\right)-5.829\right)\right) / \ln (|\mathrm{DIP}|)\right)
$$

where:

$\mathrm{T}_{\text {surf }}$ is surface temperature

DIP is dissolved inorganic $\mathrm{P}(\mu \mathrm{g} / \ell)$

As the units and corresponding ranges of observed and predicted values were fundamentally different (observed range of 0 to 996 cells $/ \mathrm{m} \boldsymbol{\ell}$ vs. predicted range of 0 to $9.02 \mathrm{~cm}^{3} / \mathrm{m}^{3}$ ), we normalised both data sets relative to their respective maxima for comparative purposes. The resulting observed and predicted values show broad temporal concordance when Ceratium was present in the lake, indicating the model's potential, although the model incorrectly predicts a continuing presence of the alga (Fig. 12a). Nonetheless, observed and predicted values were significantly correlated overall (Fig. 12b), as well as when the analysis was restricted to periods when Ceratium was actually present in the lake (Fig. 12c). The model's erroneous prediction of sustained Ceratium presence (Fig. 12a) is attributable to its underlying structure which, based on its training data, uses chlorophyll both as a major input driver (effectively a proxy for Ceratium abundance which Van Ginkel et al. (2007) did not measure directly), and again as an implicit outcome response variable. Accordingly, where Ceratium is absent and does not contribute to input level chlorophyll values, the model continues to predict Ceratium's existence, as it does not and indeed cannot distinguish the taxonomic origin of the chlorophyll level input driver. Its usefulness will accordingly be limited where Ceratium is not an ongoing component of the phytoplankton.

\section{Some direct impacts on the Albert Falls Dam ecosystem associated with Ceratium blooms}

\section{De-oxygenation}

Oxygen profiles measured at a deep, offshore mid-lake site (Station 19) in 3 successive months during 2006/2007 are shown in Fig. 13a. During the Ceratium bloom in October, severe and rapid de-oxygenation was evident below $5 \mathrm{~m}$, leading to complete anoxia below $8 \mathrm{~m}$ by early November. Some recovery (re-oxygenation) of deep-water was evident in late November (profile not shown in figure), with further recovery by January (Fig. 13a). While the oxygen profile in October was poorly concordant with the concurrent thermal profile (which lacked any sharp vertical transition), subsequent oxygen profiles were more broadly concordant with thermal conditions (Fig. 13b).

While confounded by inter- and intra-annual variability, a relatively shallow onset and severity of dissolved oxygen depletion with depth was evident in October 2006 - relative to comparable October profiles in other years (Fig. 14a). Since no equivalently wide disparity exists in the corresponding thermal profiles (Fig. 14b), the oxygen depletion observed in 2006 is most plausibly related to metabolic activity associated with the Ceratium bloom.

\section{Zooplankton abundance and community structure}

Despite the confounding influences of intra-annual variability, palpable differences in zooplankton abundance and composi-

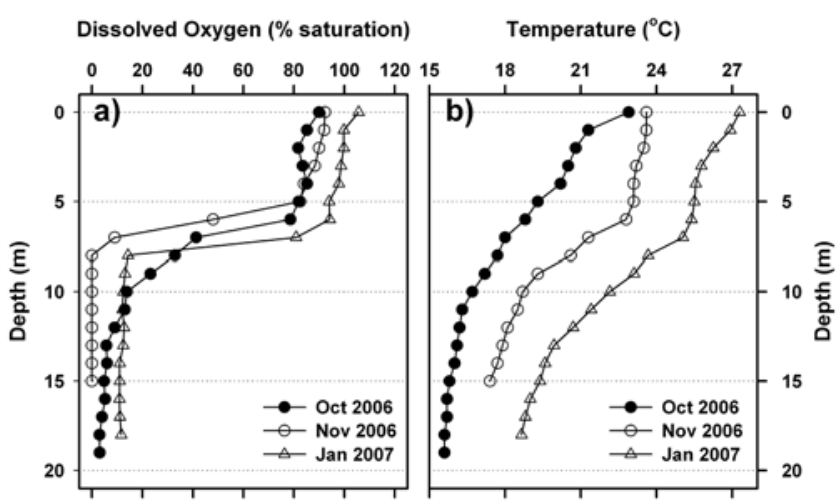

Figure 13

Temporal changes in vertical profiles of a) dissolved oxygen and b) temperature at Site 19 during the bloom event reported here.
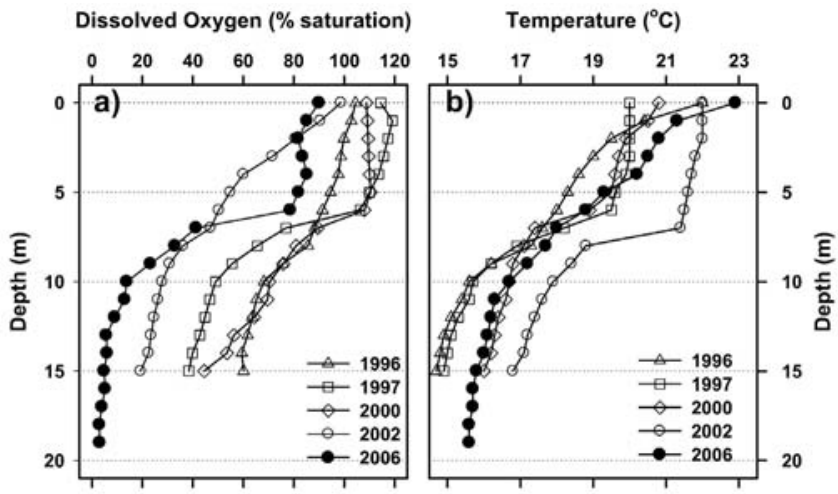

Figure 14

Comparative vertical profiles of dissolved oxygen saturation levels (a) and temperature (b) in October of various years at the same or comparable open-water site in Albert Falls Dam. The severity of oxygen depletion during the bloom in 2006 is largely unrelated to annual differences in thermal profiles - notably so in 1997 and 2002. Previous profiles recorded by Hart (2001; 2004; 2006) and unpublished.

tion were evident between the present synoptic surveys and continuous extended studies between 1989 and 1998 (Hart, 2000; 2001; 2004). We start with an overview of whole-lake zooplankton biomass distribution patterns during the synoptic surveys, which contextually assists the subsequent descriptions and evaluations of inter-annual differences.

\section{Spatial variation in biomass}

Total zooplankton biomass varied considerably over the lake during the synoptic surveys in October and January (Fig. 15), with up to 10 -fold spatial variation evident in terms of biomass per unit area (Figs. 15a and c) and per unit volume (Figs. 15b and d). In October, biomass $/ \mathrm{m}^{2}$ (Fig. 15a) increased generally from west to east, in contrast to the converse decline in chlorophyll (Fig. 3a) and Ceratium abundance. A broadly similar pattern is reflected in biomass $/ \mathrm{m}^{3}$, apart from values elevated by shallow water depth on the south-western shore, and in the north-western embayment (Fig. 15b). In January, zooplankton abundance (as $\mathrm{mg} / \mathrm{m}^{2}$ and $\mathrm{mg} / \mathrm{m}^{3}$ ) generally increased from east to west, with highest values occurring off the north-western peninsula-like intrusion into the lake (Figs. 15c and d), and with greatly elevated values in the Mgeni inflow (in contrast to October), broadly in line with elevated chlorophyll levels there 
Figure 15

Lake-wide distribution of total zooplankton biomass in Albert Falls Dam in

October $2006(a, b)$ and January 2007 (c, d).

Biomass as $\mathrm{mg} / \mathrm{m}^{2}$ in panels a) and c), and as $\mathrm{mg} / \mathrm{m}^{3}$ in panels b) and d). Sampling points correspond with those numbered in Fig. 1.
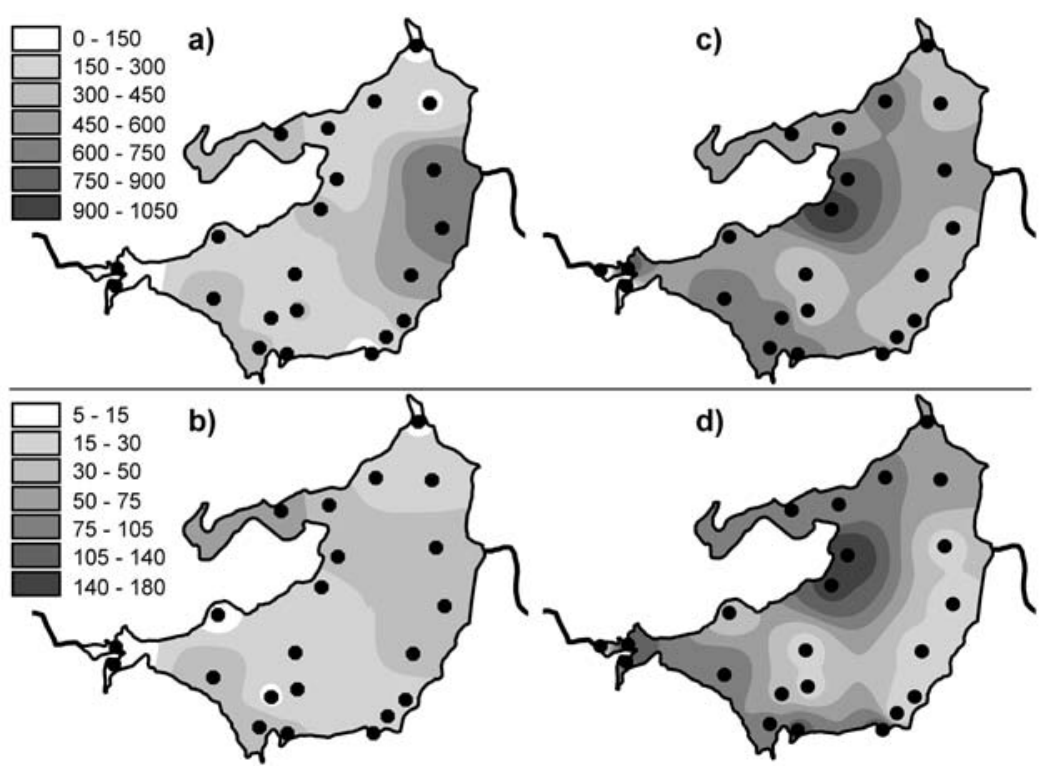
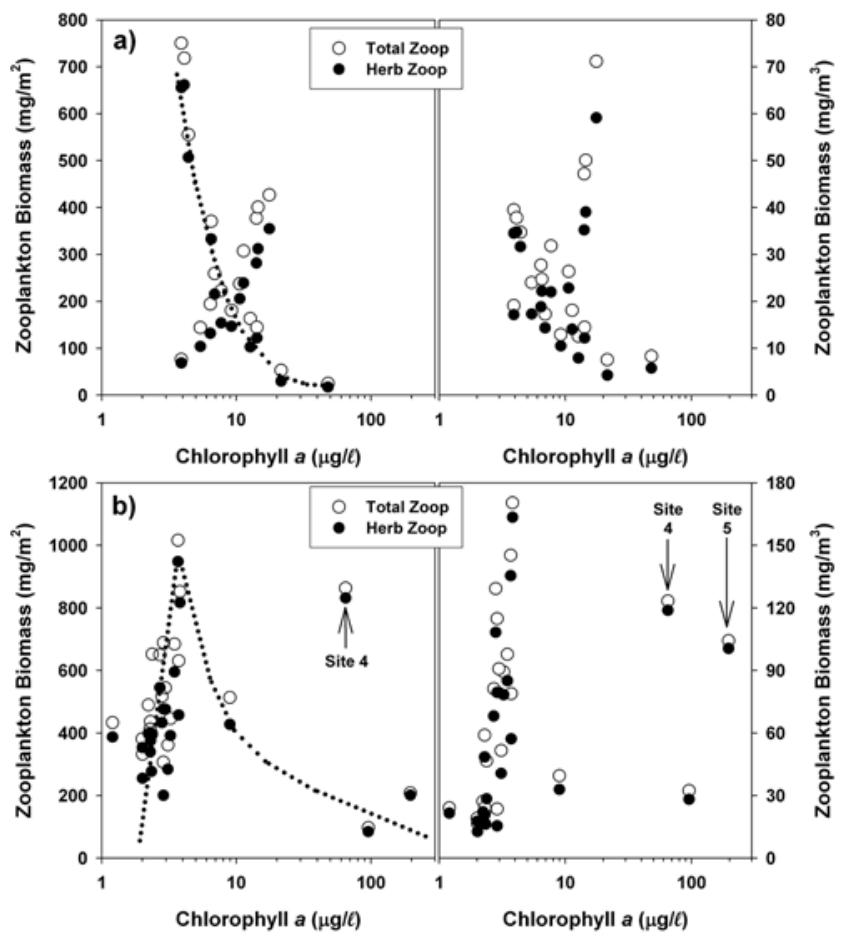

Figure 16

Lake-wide zooplankton-chlorophyll relationships in Albert Falls a) in October and b) in January, in biomass per unit area (left) and per unit volume (right). Dotted lines (fitted by eye) show general patterns for herbivores. Arrows identify apparently deviant or anomalous data at Sites 4 and 5 in January (see text).

(Fig. 3b).

The overall relationships between zooplankton abundance and chlorophyll are more transparent in simple scatter plots of these variables (Fig. 16). These reflect a general decline of both total and herbivorous zooplankton biomass above chlorophyll levels of around 3 to $4 \mu \mathrm{g} / \boldsymbol{\ell}$, which we ascribe to a depressive or inhibitory effect of Ceratium on zooplankton (see below). Two apparently anomalous cases of elevated biomass at high chlorophyll levels are evident (and arrowed) in Fig. 16b. The high value at Site 4 in the inflow plume is explicable in terms of its species composition. Abundance here was bolstered by Bosmina, Diaphanosoma and calanoid copepodites, taxa that are relatively immune to feeding disruption by large particles, and which were present here at respective densities of 5.3, 2.8 and 3.0 times the concurrent lake average. Site 5 lies in an embayment within a distinct sub-catchment somewhat isolated from the main hydraulic axis of the dam, and accordingly reflects rather localised conditions and influences. Zooplankton biomass (as $\mathrm{mg} / \mathrm{m}^{3}$ ) is here exaggerated by very shallow water depth (2 m); densities of most taxa were barely 10 to $20 \%$ of the lake average, only Diaphanosoma being marginally higher than average.

\section{Inter-annual variation in zooplankton abundance}

Zooplankton biomass over the entire lake during the present synoptic surveys was lower on average than the multiyear average values determined (at Site A) in corresponding months between 1989 and 1998 (Table 2). Conversely, however, a fairer comparison using only DOWS values suggests that zooplankton was comparably or more abundant in October 2006 and less abundant in January 2007 than the corresponding long-term averages. The (marginally) elevated zooplankton biomass values in October 2006 must be seen in the context of low densities of the dinoflagellate at these eastern sites (Fig. 3a), rather than as contradicting the depressive influence of Ceratium as suggested above.

Exclusion of drought years of high mineral turbidity, which is well-known to constrain daphniid zooplankton especially

\section{TABLE 2}

Average historical values of zooplankton abundance $\left(\mathrm{mg} / \mathrm{m}^{2}\right)$ in October and January at Albert Falls (Site A) on calendar dates closest to the synoptic survey sampling dates compared to corresponding 2006/2007 values during Ceratium blooms

\begin{tabular}{|l|c|c|}
\hline & October & January \\
\hline 9 yr average (Site A) & 566 & 749 \\
\hline $\begin{array}{l}7 \text { yr average (Site A, excluding drought } \\
\text { years) }\end{array}$ & 623 & 768 \\
\hline Synoptic survey - DOWS & 675 & 453 \\
\hline Synoptic survey - all sites & 287 & 518 \\
\hline
\end{tabular}


TABLE 3

Comparative $9 \mathrm{yr}$ and $7 \mathrm{yr}$ historical average densities (numbers $/ \mathrm{m}^{2} \pm \% \mathrm{CV}$ ) of different taxa in October and January in relation to temporally congruent averages at DOWS and for the whole lake (Sites 1 to 21) during the 2006/2007 synoptic surveys, with corresponding numerical ratios of DOWS averages in 2006/07 with the $7 \mathrm{yr}$ historical means. Change (final column) symbolises the differences as: No change distinguishable ( ); discernible increase (+) or decrease (-); clear increase (++) or decrease (--); profound increase (+++); effective or complete disappearance ( lost or lost); new appearance (new).

\begin{tabular}{|c|c|c|c|c|c|c|}
\hline & \multicolumn{2}{|c|}{ Historical averages } & \multicolumn{2}{|c|}{$2006 / 07$} & \multicolumn{2}{|c|}{ DOWS: 7 yr mean } \\
\hline OCTOBER & $9 \mathrm{yr}$ & $7 \mathrm{yr}$ & DOWS & All sites & Ratio & Change \\
\hline Daphnia & $35568 \pm 46$ & $40474 \pm 36$ & $51758 \pm 17$ & $16526 \pm 97$ & 1.28 & + \\
\hline Ceriodaphnia & 0 & 0 & 0 & 0 & & $\sim$ \\
\hline Bosmina & $45 \pm 300$ & $58 \pm 265$ & $1188 \pm 65$ & $1948 \pm 102$ & 20.48 & +++ \\
\hline Diaphanosoma & $23 \pm 300$ & 0 & 0 & 0 & & $\sim$ \\
\hline Moina & $258 \pm 300$ & 0 & 0 & 0 & & $\sim$ \\
\hline Calanoids & $6585 \pm 70$ & $6375 \pm 77$ & $6448 \pm 36$ & $6915 \pm 71$ & 1.01 & $\sim$ \\
\hline Cyclopoids & $79268 \pm 52$ & $87760 \pm 47$ & $131685 \pm 20$ & $95312 \pm 53$ & 1.50 & + \\
\hline Chaoborus & $1106 \pm 83$ & $1245 \pm 76$ & $1867 \pm 16$ & $1782 \pm 89$ & 1.51 & + \\
\hline Total $/ \mathrm{m}^{2}$ & $122853 \pm 46$ & $135912 \pm 42$ & $192945 \pm 18$ & $122483 \pm 50$ & 1.42 & + \\
\hline \multicolumn{7}{|l|}{ JANUARY } \\
\hline Daphnia & $16780 \pm 97$ & $18656 \pm 93$ & $85 \pm 173$ & $69 \pm 257$ & 0.005 & $\sim$ Lost \\
\hline Ceriodaphnia & $23780 \pm 199$ & $30537 \pm 172$ & $15782 \pm 17$ & $14463 \pm 122$ & 0.52 & -- \\
\hline Bosmina & 0 & 0 & $7297 \pm 30$ & $9164 \pm 117$ & $\infty$ & New \\
\hline Diaphanosoma & $40435 \pm 136$ & $23715 \pm 69$ & $35042 \pm 16$ & $45934 \pm 56$ & 1.48 & + \\
\hline Moina & $6851 \pm 240$ & $1079 \pm 122$ & 0 & 0 & 0.00 & Lost \\
\hline Calanoid copepods & $10813 \pm 60$ & $11872 \pm 55$ & $34279 \pm 10$ & $40068 \pm 90$ & 2.89 & ++ \\
\hline Cyclopoid copepods & $125458 \pm 62$ & $133059 \pm 60$ & $102158 \pm 7$ & $134111 \pm 53$ & 0.77 & - \\
\hline Chaoborus & $1439 \pm 54$ & $1419 \pm 42$ & $2036 \pm 76$ & $3031 \pm 94$ & 1.43 & + \\
\hline Total $/ \mathrm{m}^{2}$ & $225557 \pm 54$ & $220338 \pm 48$ & $196679 \pm 3$ & $246840 \pm 38$ & 0.89 & - \\
\hline
\end{tabular}

(e.g. Hart, 1988; Kirk, 1991), results in higher 7-year than 9-year average values in Table 2. For the 7-year averages, values for 1993 and 1995 with corresponding Secchi depths of 30 and $15 \mathrm{~cm}$, were excluded from the October calculations; for January, values for 1993 and 1994 (Secchi depths of 75 and 40 $\mathrm{cm})$, were excluded. Congruent Secchi depth values in other years ranged from 100 to $280 \mathrm{~cm}$.

\section{Inter-annual variation in zooplankton community composition}

Table 3 summarises comparative data on zooplankton abundance and composition during the synoptic surveys (for the entire lake as well as for DOWS), with temporally congruent historical records at Site A. The DOWS subset is compared with historical data for Site A in NMDS ordinations (Fig. 17), the low stress values of which (0.05 and 0.03 for Figs. 17a and $17 \mathrm{~b}$, respectively) indicate that most of the year-to-year variation is accounted for. Table 3 and Fig. 17 should be considered together.

The relative distance between years in the ordinations reflects similarity in community composition. Both in October (Fig. 17a) and in January (Fig. 17b), the community in 2006/07 was highly distinct from the communities of previous years; only during the January 1993 to January 1994 drought (and inexplicably in the post-drought January 1996, when a Secchi depth of $110 \mathrm{~cm}$ still indicated relatively high turbidity) was the community as distinct as the 2006/07 community was from a)

Figure 17

Non-metric multi-

dimensional scaling representations of year-to-year variation in Albert Falls zooplankton community composition in October (a) and January (b) at DOWS (2006/2007) and Site A (1989-1998), based on numbers $/ \mathrm{m}^{2}$ of each taxon.

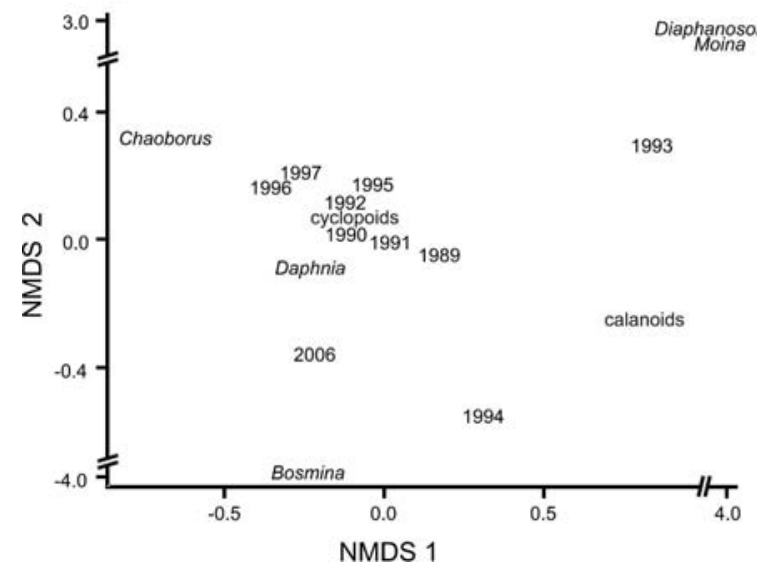

NMDS 1 b)

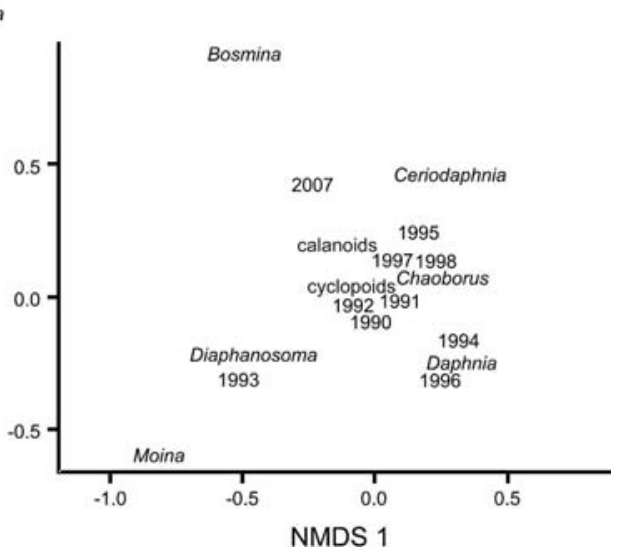


that of the other, higher-rainfall years. During the 1993-1995 drought, reduction of Site A haul depths to as little as $5 \mathrm{~m}$, from a mean of $16 \mathrm{~m}$ in other years, would have reduced abundance levels per unit area simply by reducing water column volume per unit surface area (see Methods). But, in addition, winddriven re-suspension of sediment led to profound changes in community structure (Hart, 2004). The Ceratium bloom in 2006/07 appears to have been associated with a shift in community structure similar in magnitude to that associated with the drought, although given the gap in the zooplankton record from 1998 to 2005 we do not know if this shift in community structure coincided with, or pre-dated, the bloom.

Distances between taxa and years in ordination space reflect relative abundances; a taxon is abundant in a particular year if it lies close to that year (relative to other taxa), and is (relatively) scarce in years that lie far away from it. Moina, abundant in previous Januaries, was absent in 2007 (Fig. 17b, Table 3). Daphnia were also much less abundant in 2006/07 than in previous non-drought years (Fig. 17); that they also appeared scarcer in October in the very turbid drought year of 1993 (Secchi depth $30 \mathrm{~cm}$ ) and the moderately turbid lowwater year of 1994 (Secchi depth $100 \mathrm{~cm}$ ) than during the Ceratium bloom in 2006 (resulting in lower historical means for Daphnia in October; Table 3) may be an artefact of reduced haul-depth during those years. In contrast, Bosmina was far more abundant, both in October 2006 and January 2007, than in previous years (Fig. 17, Table 3). Chaoborus densities in deep water sites were also higher in 2006/2007 than historically (Table 3), while calanoid copepods were nearly 3 times more abundant at these deep sites in January 2007 than they were in previous years (Fig. 17b, Table 3). Cyclopoid copepods were 50\% more abundant in deep sites in October 2006 than historically (Table 3). They also showed strikingly greater species diversity during 2006/2007 than historically, with 3 species of Tropocyclops of radically dissimilar size co-occurring with a species each of Mesocyclops and Thermocyclops in many samples. The appearance of a chydorid cladoceran (Chydorus spp. - not included in Table 3) for the first time, abundantly in the inflow plume, albeit sparsely in open-water samples, is consistent with the common perception of chydorids as bio-indicators of eutrophic conditions (e.g. De Eyto, 2001).

We attribute much of this change to the emergence of Ceratium as an overwhelming (October) or prominent (January) constituent of the phytoplankton, mediated through its influences on zooplankton feeding and hence community structure. Food resources are well known to exert profound effects on zooplankton abundance and composition through one or more major avenues of influence (e.g. Sterner and Schulz, 1998; DeMott et al., 2004; Becker, 2004):

- Physical constraints to consumption, including morphology and size (edibility)

- Food quality - a composite influence involving elemental composition, nutrient stoichiometry and limitation (of $\mathrm{P}$ in particular), as well as biochemical limitation by amino acids, vitamins, and especially fatty acids

- Chemical deterrents, toxicity, palatability and digestion resistance

However, the actual feeding mechanisms employed by different zooplankters exert an overriding primary control - that of food particle acquisition. It is in this context that we primarily attribute Ceratium's influence on zooplankton composition favouring Bosmina and calanoid copepods, while inhibiting
Daphnia and Moina (as explained below).

Bosmina has been characterised as an 'undergrowth' taxon - able to find and feed on diffuse small food particles (including bacteria) in a nutritional environment overwhelmed by large, mostly inedible particles (Sommer et al., 1986). Similarly, the raptorial feeding mechanism of calanoid (and cyclopoid) copepods allows them to very selectively locate scarce suitable food particles (Koehl and Strickler, 1981; Strickler, 1984; Vanderploeg and Paffenhofer, 1985; Paffenhofer and Lewis, 1990; Brandl, 1998). Conversely, Daphnia employs non-selective bulk filtration, a mode of food collection that greatly compromises it when suspended particles are predominantly non-nutritive, as in the case of waters of high clay turbidity (Hart, 1988; Kirk, 1991; 1992), or nutritionally inferior or incomplete, as in eutrophic waters with large filamentous or colonial algae, especially cyanophytes (Jarvis et al., 1987). Food collection is correspondingly compromised in the presence of large particles like Ceratium. The absence of Moina is also attributable to the impact of Ceratium on the suspended food environment. While able to feed on a wide size range of particles, Moina is affected by their prevailing nature and size distribution (Pagano, 2008), and is compromised when large particles prevail. Diaphanosoma, a more selective feeder controlled by the availability of small food particles (Pagano, 2008), was surprisingly some 50\% commoner in January than historically - perhaps exploiting bacterioplankton associated with decomposing Ceratium, or particulates in influent wastewater.

The higher abundance of Chaoborus is consistent with the parallel increases in potential prey such as cyclopoids (and/or Ceratium, as noted by Xie et al., 1998) in October, and to an abundance of Bosmina and Diaphanosoma in January. Further, despite the low retention of rotifers by $160 \mu \mathrm{m}$ pre-screening, a numerical prominence of rotifers was evident in many January samples, especially in the Mgeni inflow plume, offering an additional food source for cyclopoids and Chaoborus in turn. Cyclopoid copepods were 50\% more numerous than historically in deep water sites in October, but some $20 \%$ scarcer in January (Table 3), although exhibiting particularly high densities in the inflow plume regions. As selective raptorial feeders, cyclopoids are unlikely to be compromised by high Ceratium densities, while the proliferation of rotifers in the inflow regions in January would conversely afford a rich food environment. As calanoid copepods are reported to competitively suppress cyclopoids (e.g. Soto and Hurlbert, 1991), their greater abundance in January 2007 (Table 3) offers a plausible explanation for the corresponding depression of cyclopoids.

Broadly parallel changes in zooplankton community structure associated with blooms of Ceratium in a eutrophic, fishless pond were reported by Xie et al. (1998). They observed a major collapse of Daphnia, attributed to a shortage of edible algae and feeding inhibition during blooms of Ceratium. Conversely Chaoborus, typically a 'carnivorous' predator, increased dramatically as they switched to consume the abundant Ceratium.

\section{Ecological thresholds}

In all likelihood, the sudden appearance of dinoflagellate blooms reported here is attributable to surpassing an ecological threshold (Groffman et al., 2006), in this case, namely, that of prevailing nutrient concentration. While the data available do not permit an identification of the actual threshold level involved, exponential enrichment of Albert Falls with P (Figs. 9 and 10) manifests clearly and inescapably as a causal factor for the ecological 'switch' observed here. 
The emergence of Ceratium at bloom densities results in a variety of undesirable consequences, ranging from its nuisance value in clogging water purification filters through to its various impacts on affected aquatic ecosystems. With regard to the latter, the observed re-structuring of zooplankton composition accompanying or associated with its appearance at high densities is highly undesirable in terms of sustaining ecological services beneficial to humans. For example, the reduction or loss of large-bodied Daphnia in particular reduces natural filtration rates of the dam water, removing some natural controls on algal proliferation. It also reduces food resources for juvenile fish that in turn serve as food for and influence populations of an economically valuable fish species - bass - for which Albert Falls is a premier angling venue of national importance. Such consequences are neither ecologically nor economically trivial, and consideration of mitigation prospects is required.

\section{Management prospects for mitigation}

Based on the above identification of sharply rising TP concentrations in inflow waters, with associated lower N:P ratios (based on $\mathrm{NO}_{3}-\mathrm{N}$ :TP values) as contributory or causal factors leading to bloom formations of this dinoflagellate, and the inference that this change in nutrient stoichiometry arises from increasing P loading from the local WWT plant, it seems certain that bloom formation can be reduced, if not avoided, by improved compliance with WWT effluent standards and associated release management. Operational deficiencies in WWT plant management and quality control have been widely publicised as an increasing national problem in recent press articles and an extensive 'grey literature'. The following excerpt from a news report by Munnik (2008) paraphrases the problem: 'Since 2004 a spate of surveys and technical papers have noted that up to 70 percent of municipal waste-treatment works face collapse for lack of proper maintenance and extension, while around a third require "immediate intervention" and another third intervention "within the short to medium term".' Apart from routine operational problems, WWT facilities also face increasing loads, commonly exceeding their design capacity. Thus, even where prescribed effluent standards (e.g. $0.5 \mathrm{mg} / \boldsymbol{\ell}$ P) are upheld by WWT plants, consideration of total discharge volumes is also necessary, given the explosive increase in residential units connected to individual sewerage reticulation networks. Implementation of (and adherence to) specified total nutrient loading limits is clearly required in addition to corrective measures to maintain specified effluent standards; such standards need also to be upgraded to more stringent levels. These various corrective measures need urgent attention if the rampant pollution spiral is to be halted, and preferably reversed, in Albert Falls as in other strategically crucial reservoirs. Our observations lend unambiguous support to the need also for a judicious approach to human population expansion in the Midmar catchment, including proposed housing developments such as Khayelisha/ Holly Wood.

\section{Acknowledgments}

This investigation was stimulated by field courses run over 2 weekends for students enrolled in the Ecosystem Ecology and Management course (Ecology312) at the University of KwaZulu-Natal (UKZN) in 2006. Sarah Baxter, Natassja Bush, Anje de Wet, Megan Fitzgerald, Terrence Liversage, Thembeka Nxele, Tracy Odendaal, Gail Potgieter, Wade
Shrives, Jade Tegg, Kate Watts, Amy Wilson and Peter Wragg were guided to undertake the initial field sampling in October which exposed the existence of a Ceratium bloom. Justin Hart assisted in the January 2007 lake survey. Umgeni Water, the parastatal water utility responsible for this catchment, kindly provided access to and permission to use their historical records of water quality (nutrients and algae); special thanks to Dr. Steve Terry for resolving various queries regarding these raw data, and for supplying GIS base layers. The chlorophyllprofiling fluoroprobe spectrofluorometer was kindly loaned by Prof. Renzo Perissinotto (UKZN-Durban campus).

\section{References}

BECKER C (2004) Living with Constraints - Food Quality Effects on Zooplankton. Ph.D. Dissertation. University of Kiel, Germany. 115 pp.

BRANDL Z (1998) Feeding strategies of planktonic cyclopoids in lacustrine ecosystems. J. Mar. Syst.15 87-95.

BUCK H and ZUREK R (1994) Trophic relations between phyto- and zooplankton in a field experiment in the aspect of the formation and decline of water blooms. Acta Hydrobiol. 34 139-155.

DeMOTT WR, EDINGTON JR and TESSIER AJ (2004) Testing zooplankton food limitation across gradients of depth and productivity in small stratified lakes. Limnol. Oceanogr. 49 1408-1416.

DE EYTO E (2001) Chydorus sphaericus as a biological indicator of water quality in lakes. Verh. Int. Ver. Limnol. 27 3358-3362.

FREMPONG E (1984) A seasonal sequence of diel distribution patterns for the planktonic Dinoflagellate Ceratium hirundinella in a eutrophic lake. Freshwater Biol. 14 401-421.

GRIGORSZKY I, PADISÁK J, BORICS G, SCHITCHEN C and BORBÉLY G (2003) Deep chlorophyll maximum by Ceratium hirundinella (O.F. Müller) Bergh in a shallow oxbow in Hungary. Hydrobiol. 506-509 209-212.

GROFFMAN PM, BARON JS, BLETT T, GOLD AJ, GOODMAN I, GUNDERSON LH, LEVINSON BM, PALMER MA, PAERL HW, PETERSON GD, LEROY POFF N, REJESKI DW, REYNOLDS JF, TURNER MG, WEATHERS KC and WIENS J (2006) Ecological thresholds: The key to successful environmental management or an important concept with no practical application? Ecosyst. 9 $1-13$

HANSEN A-M and SANTER B (1995) The influence of food resources on the development, survival and reproduction of the two cyclopoid copepods: Cyclops vicinus and Mesocyclops leuckarti. J. Plankton Res. 17 631-646.

HART RC (1988) Zooplankton feeding rates in relation to suspended sediment content: potential influences on community structure in a turbid reservoir. Freshwater Biol. 19 123-139.

HART RC (2000) Comparative long-term periodicity of Diaphanosoma excisum in adjacent warm-water impoundments, with an evaluation of contributory factors. Verh. Int. Ver. Limnol. 27 19331939.

HART RC (2001) Two calanoids, two lakes, and a decade or two. An updated record and evaluation of occurrence and periodicity of Tropodiaptomus spectabilis and Metadiaptomus meridianus (Copepoda: Calanoida), and alternative stable states in two cascading impoundments. Hydrobiol. 453 269-283.

HART RC (2004) Cladoceran periodicity patterns in relation to selected environmental factors in two cascading warm-water reservoirs over a decade. Hydrobiol. 526 99-117.

HART RC (2006) Phytoplankton dynamics and periodicity in two cascading warm-water reservoirs from 1989 to 1997 - taxonomic and functional (C-S-R) patterns, and determining factors. Water SA 32 (1) 81-92

HEANEY SI (1976) Temporal and spatial distribution of the dinoflagellate Ceratium hirundinella O.F. Muller within a small productive lake. Freshwater Biol. 6 531-542.

HEANEY SI and FURNASS TI (1980) Laboratory models of diel vertical migration in the dinoflagellate Ceratium hirundinella. Freshwater Biol. 10 163-170. 
JAMES WF, TAYLOR WD and BARKO JW (1992) Production and vertical migration of Ceratium hirundinella in relation to phosphorus availability in Eau Galle Reservoir, Wisconsin. Can. J. Fish. Aquat. Sci. 49 (4) 694-700.

JARVIS AC, HART RC and COMBRINK S (1987) Z ooplankton feeding on size fractionated Microcystis colonies and Chlorella in a hypertrophic lake (Hartbeespoort Dam, South Africa) - implications to resource utilization and zooplankton succession $J$. Plankton Res. 9 1231-1249.

KEINZLE SW, LORENTZ SA and SCHULZE RE (1997) Hydrology and water quality of the Mgeni Catchment. WRC Report No. TT 87/97. Water Research Commission, Pretoria, South Africa. 87 pp.

KIRK KL (1991) Suspended clay reduces Daphnia feeding rate. Behavioural mechanisms. Freshwater Bio, 25 357-365.

KIRK KL (1992) Effects of suspended clay on Daphnia body growth and fitness. Freshwater Biol. 28 103-109.

KOEHL MAR and STRICKLER JR (1981) Copepod feeding currents: Food capture at low Reynolds number. Limnol. Oceanogr. 261062 1073.

MACDONAGH ME, CASCO MA and CLAPS MC (2005) Colonization of a neotropical reservoir (Córdoba, Argentina) by Ceratium hirundinella (O. F. Müller) Bergh. Ann. Limnol. 41 291-299.

MOSS B (1998) Shallow lakes biomanipulation and eutrophication. SCOPE Newsletter 29 1-45.

MUNNIK V (2008) Sewerage shapes up as next crisis. Cape Times, 18 March 2008

OKSANEN J, KINDT R, LEGENDRE P, O'HARA B, SIMPSON GL and STEVENS MHH (2008) vegan: Community Ecology Package. R package version 1.11-4. URL: http://cran.r-project.org; http:// vegan.r-forge.r-project.org

PADISÁK J (1985) Population dynamics of the freshwater dinoflagellate Ceratium hirundinella in the largest shallow lake of Central Europe, Lake Balaton, Hungary. Freshwater Biol. 15 43-52.

PAFFENHOFER G-A and LEWIS KD (1990) Perceptive performance and feeding behaviour of calanoid copepods. J. Plankton Res. 12 933-946.

PAGANO M (2008) Feeding of tropical cladocerans (Moina micrura, Diaphanosoma excisum) and rotifer (Brachionus calyciflorus) on natural phytoplankton: effect of phytoplankton size-structure. J. Plankton Res. 30 401-414.

PARODI ER, TROBBIANI N and CÁCERES EJ (2007). Cytomorphometric characterization of a population of Ceratium hirundinella fa. austriacum (Dinophyta) during a bloom in a reservoir of the Province of Buenos Aires, Argentina . Algol. Stud 125 45-55.

PÉREZ-MARTÍNEZ C and SÁNCHEZ-CASTILLO P (2001) Temporal occurrence of Ceratium hirundinella in Spanish reservoirs. Hydrobiol. 452 101-107.
PÉREZ-MARTÍNEZ C and SÁNCHEZ-CASTILLO P (2002) Winter dominance of Ceratium hirundinella in a southern north-temperate reservoir. J. Plankton Res. 24 89-96.

REYNOLDS CS (1996) The plant life of the pelagic. Verh. Int. Ver. Limnol. 26 97-113.

REYNOLDS CS (2006) The Ecology of Phytoplankton. Cambridge University Press, Cambridge, UK. 535 pp.

SOMMER U, GLIWICZ ZM, LAMPERT W and DUNCAN A (1986) The PEG model of seasonal succession of planktonic events in fresh waters. Arch. Hydrobiol. 106 433-471.

SOTO D and HURLBERT SH (1991) Short-term experiments on calanoid-cyclopoid-phytoplankton interactions. Hydrobiol. 215 83-110.

STRICKLER JR (1984) Sticky water: A selective force in copepod evolution. In: Meyers DG and Strickler JR (eds.) Trophic Interactions within Aquatic Ecosystems. Westview Press, Boulder, USA. 187-239.

STERNER RW and SCHULZ KL (1998) Zooplankton nutrition: recent progress and a reality check. Aquat. Ecol. 32 261-279.

TALLING J F (2004) Interrelation of diel and seasonal change, involving summer thermal stratification, weather variables and a mobile dinoflagellate in a productive English lake. Hydrobiol. 524 215-227.

VANDERPLOEG HA and PAFFENHOFER G-A (1985) Modes of algal capture by the freshwater copepod Diaptomus sicilus and their relation to food-size selection. Limnol. Oceanogr. 30 871-885.

VAN GINKEL CE, HOHLS BC and VERMAAK E (2001) A Ceratium hirundinella (O.F. Müller) bloom in Hartbeespoort Dam, South Africa. Water SA 27 (2) 269-276.

VAN GINKEL CE, CAO H, RECKNAGEL F and DU PLESSIS S (2007) Forecasting of dinoflagellate blooms in warm-monomictic hypertrophic reservoirs in South Africa by means of rule-based agents. Water SA 33 (4) 531-538.

VAN GINKEL CE and SILBERBAUER MJ (2006) Personal communication: unpublished internal report/manuscript entitled "The Seasonal and Temporal Distribution and Incidence of Ceratium hirundinella (O.F. Müller) Bergh in South African Freshwater Resources”.

WHITTINGTON JL, SHERMAN B, GREEN D and OLIVER RL (2000) Growth of Ceratium hirundinella in a subtropical Australian reservoir: the role of vertical migration. J. Plankton Res. 22 1025-1045.

XIE P, IWAKUMA T and FUJII K (1998) Changes in the structure of a zooplankton community during a Ceratium (dinoflagellate) bloom in a eutrophic fishless pond. J. Plankton Res. 20 1663-1678. 